\title{
Neotectonics of Graciosa island (Azores): a contribution to seismic hazard assessment of a volcanic area in a complex geodynamic setting
}

\author{
Ana Hipólito ${ }^{1, \star}, J^{\prime}$ osé Madeira ${ }^{2}$, Rita Carmo ${ }^{1,3}$, João Luís Gaspar ${ }^{1,3}$ \\ ${ }^{1}$ Centro de Vulcanologia e Avaliação de Riscos Geológicos da Universidade dos Açores, Açores, Portugal \\ ${ }^{2}$ Universidade de Lisboa, Faculdade de Ciências, Departamento de Geologia, and Instituto Dom Luiz (Laboratório \\ Associado)-IDL(LA), Lisboa, Portugal \\ ${ }^{3}$ Centro de Informação e Vigilância Sismovulcânica dos Açores, CIVISA, Açores, Portugal
}

Article history

Received October 8, 2012; accepted May 10, 2013.

Subject classification:

Structural geology, Stress, Plate boundaries, motion and tectonics, Geodynamics, Seismic risk.

\section{ABSTRACT}

Graciosa is a mid-Pleistocene to Holocene volcanic island that lies in a complex plate boundary between the North American, Eurasian, and Nubian plates. Large fault scarps displace the oldest (Middle Pleistocene) volcanic units, but in the younger areas recent volcanism (Holocene to Upper Pleistocene) conceals the surface expression of faulting, limiting neotectonic observations. The large displacement accumulated by the older volcanic units when compared with the younger formations suggests a variability of deformation rates and the possibility of alternating periods of higher and lower tectonic deformation rates; this would increase the recurrence interval of surface rupturing earthquakes. Nevertheless, in historical times a few destructive earthquakes affected the island attesting for its seismic hazard. Regarding the structural data, two main fault systems, incompatible with a single stress field, were identified at Graciosa Island. Thus, it is proposed that the region is affected by two alternating stress fields. The stress field \#1 corresponds to the regional stress regime proposed by several authors for the interplate shear zone that constitutes the Azorean segment of the Eurasia-Nubia plate boundary. It is suggested that the stress field \#2 will act when the area under the influence of the regional stress field \#1 narrows as a result of variations in the differential spreading rates north and south of Azores. The islands closer to the edge of the sheared region will temporarily come under the influence of a different (external) stress field (stress field \#2). Such data support the concept that, in the Azores, the Eurasia-Nubia boundary corresponds to a complex and wide deformation zone, variable in time.

\section{Geodynamic and volcanic setting}

The Azores archipelago lies on a complex geodynamic setting on the triple junction between the Eurasian (Eu), North American (NA), and Nubian (Nu) plates (Figure 1). Graciosa Island is located on the west-

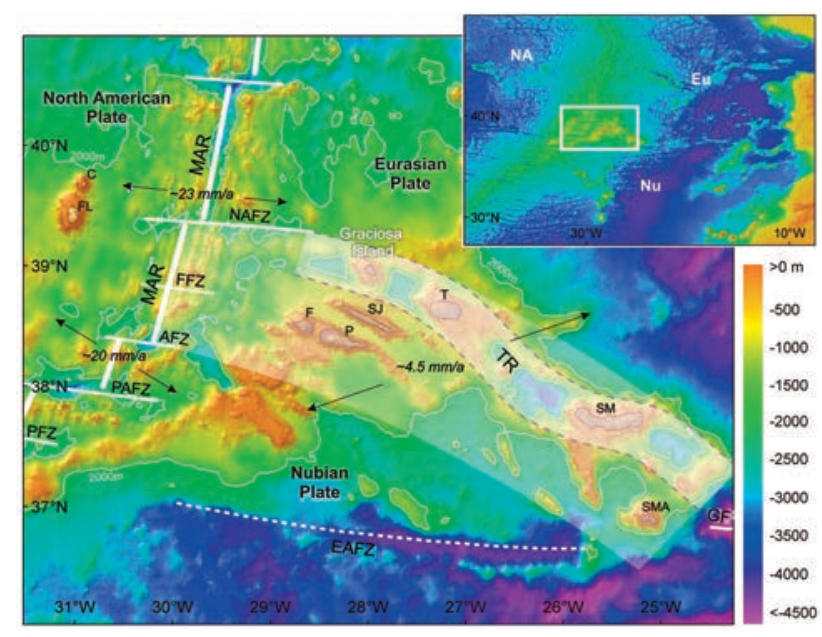

Figure 1. Main morphotectonic features of Azores region. White lines define approximately the morphological expression of each structure; white shaded area represents the sheared western segment of the Eu-Nu plate boundary, whereas the white shaded area limited by a dotted grey line represents its main structure, the Terceira Rift (TR). Plates: Eu - Eurasia; Nu - Nubia; NA - North America; Tectonic structures: MAR - Mid-Atlantic Ridge; EAFZ - East Azores Fracture Zone; NAFZ - North Azores Fracture Zone; GF Gloria Fault; FFZ - Faial Fracture Zone; AFZ - Açor Fracture Zone; PAFZ - Princesa Alice Fracture Zone; PFZ - Pico Fracture Zone. Islands: SMA - Santa Maria; SM - São Miguel; T - Terceira; SJ - São Jorge; P - Pico; F - Faial; FL - Flores; C - Corvo. Azores bathymetry adapted from Lourenço et al. [1997]; World topography and bathymetry from GEBCO_08 database [2010]. Datum: WGS 1984.

ern segment of the Eu-Nu boundary, which is characterized by diffuse and complex deformation in a dextral transtensile tectonic regime [e.g. Lourenço et al. 1998, Madeira and Brum da Silveira 2003, Carmo 2004, Hipólito 2009] (Figure 1). This boundary acts as an ultra-slow (ca. $4.5 \mathrm{~mm} / \mathrm{a}$-DeMets et al. 2010) oblique 
spreading centre [Vogt and Jung 2004] and as a transfer zone accommodating the differential motion between $\mathrm{Eu}$ and $\mathrm{Nu}$ plates, due to the higher spreading rates and slightly different spreading direction north of Azores [DeMets et al. 1994, Sella et al. 2002, Altamimi et al. 2002, Fernandes et al. 2003, Kreemer et al. 2003, Calais et al. 2003, DeMets et al. 2010]. The stress regime, the tectonic processes, and the segmentation patterns of the western segment of the Eu-Nu plate boundary are still a matter of debate. This boundary does not correspond to a discrete structure but to a wide $(\sim 150 \mathrm{~km})$ large-scale interplate shear zone, and the islands within this region present average motions that are intermediate to those predicted by global plate motion models for $\mathrm{Eu}$ and $\mathrm{Nu}$ [Fernandes et al. 2006, Trota 2008, Miranda et al. 2012, Mendes et al. 2013]. Graciosa and Santa Maria islands, the emerged areas closer to the north and south edges of the plate boundary zone, display kinematic behaviours close to those predicted for stable $\mathrm{Eu}$ and $\mathrm{Nu}$, respectively [Fernandes et al. 2006].

Some authors [e.g. Schilling 1975, Cannat et al. 1999, Escartín et al. 2001, Gente et al. 2003, Madureira et al. 2005, Silveira et al. 2006, Yang et al. 2006] consider that the intense magmatism in the region results from a ridge-hotspot interaction. Shifting of the plate boundary, possibly associated to migration of the hotspot [e.g. Vogt and Jung 2004], created a topographically disturbed area which has been successively attached to the $\mathrm{Nu}$ plate as the triple junction jumped northwards [Luis and Miranda 2008]. This region - the Azores Plateau [Needham and Francheteau 1974] - is characterized by an anomalously thick ocean crust [e.g. Hirn et al. 1980, Luís et al. 1998, Miranda et al. 1998, Dias et al. 2007] and shallow depths relatively to the surrounding sea-floor.

The neotectonic data [e.g. Madeira and Brum da Silveira 2003] on the islands show a structural pattern indicating three-dimensional strain [Reches 1983, Reches and Dieterich 1983], represented by two main conjugated sets of faults with oblique slip (Figure 2): (1) the main system, trending WNW-ESE to NW-SE, with normal dextral oblique displacement is parallel to the inter-plate shear zone; and (2) the NNW-SSE trending conjugate system, with normal sinistral oblique displacement, is oblique to the plate boundary direction. The stress field is characterized by horizontal maximum compressive stress axis $(\sigma 1)$ trending NW-SE in the axial area of the shear zone (which rotates to N-S near Santa Maria island; Madeira [1986], Figure 2), horizontal maximum tensile stress axis ( $\sigma 3)$ trending NESW (rotating to E-W in Santa Maria Island; Madeira [1986], Figure 2), and vertical intermediate compressive stress axis $(\sigma 2)$. Permutations between $\sigma 1$ and $\sigma 2$ after stress drop events during transtensile phases, as proposed by Reches [1983], account for alternating transtensile and tensile regimes [Madeira 1998]. The changing regimes are deduced both from slickensides indicating events in strike-slip, oblique slip, or normal slip in the same fault, and from different focal mechanisms of earthquakes in faults with the same direction (Table 1). In the eastern edge of the deformation zone (eastern part of São Miguel) a distinct set of WNW-ESE to NW-SE normal left-lateral faults conjugated with NE-
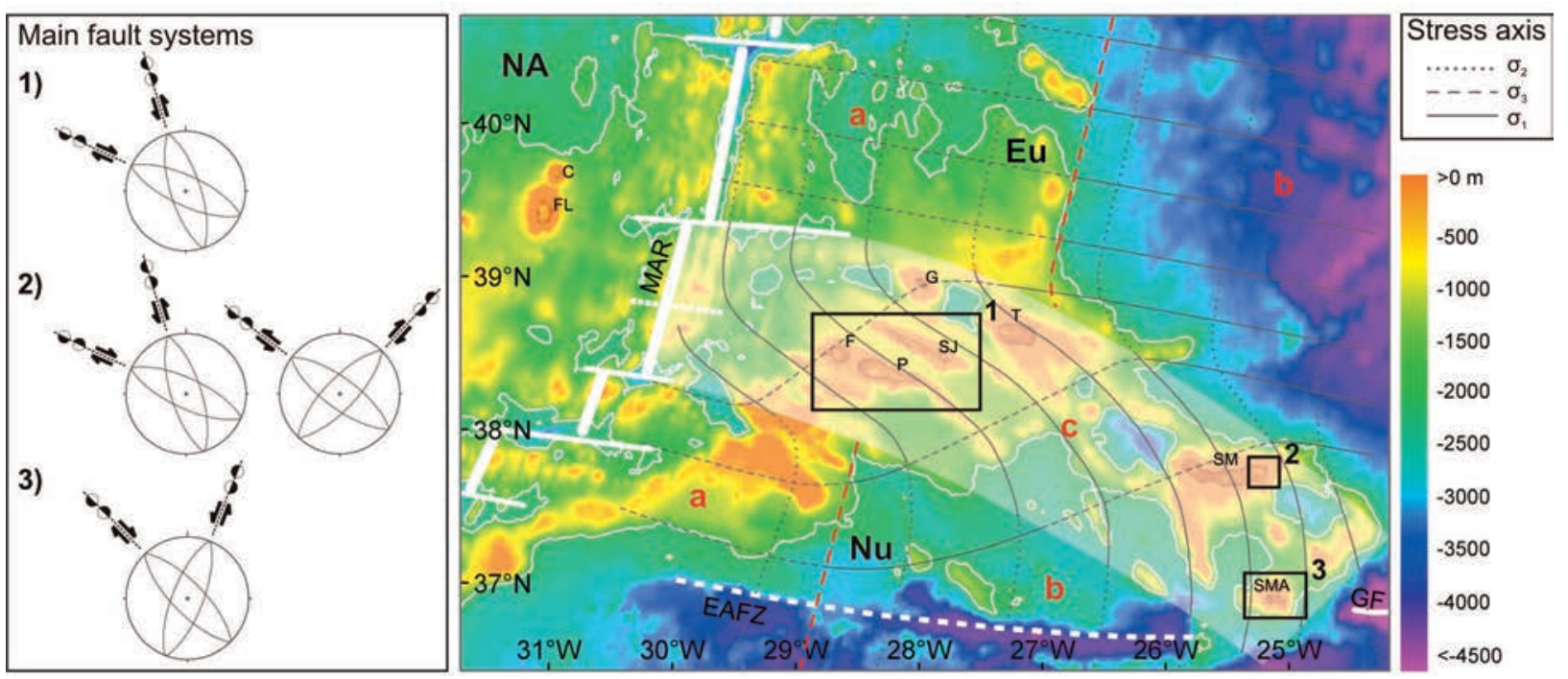

Figure 2. Stress pattern and stereographic plots of the main fault systems of the Azores region as inferred from neotectonic data [Madeira 1986, Madeira and Ribeiro 1990, Madeira 1998, Lourenço et al. 1998, Carmo 2004]. The tensile stress field (a) close to the MAR passes laterally to compressive (b) as the sea-floor moves away from the ridge. Inside the sheared region (c) stress permutation and deviation of stress trajectories occur. Red dashed lines separate the different stress field domains; White shaded area represents the interplate sheared region. Acronyms as in Figure 1. Bathymetry adapted from Lourenço et al. [1997]. Datum: WGS 1984 (modified from Madeira [1998], Lourenço et al. [1998] with data from Carmo [2004]). 


\begin{tabular}{|c|c|c|c|c|c|c|c|c|c|c|}
\hline Event $n^{\circ}$ & $\begin{array}{c}\text { Date } \\
(\mathrm{d} / \mathrm{m} / \mathbf{y r})\end{array}$ & $\begin{array}{l}\text { Loca } \\
\text { Latitude } \\
\left({ }^{\circ} \mathbf{N}\right)\end{array}$ & $\begin{array}{l}\text { Lation } \\
\qquad \begin{array}{c}\left.{ }^{\circ} \mathrm{E}\right) \\
\text { Longitude }\end{array}\end{array}$ & $\begin{array}{c}\text { Depth } \\
(\mathbf{k m})\end{array}$ & $\mathbf{M}$ & $\begin{array}{c}\text { Mo } \\
\left(\mathbf{x 1 0}^{17} \mathrm{Nm}\right)\end{array}$ & Strike & Rake & Dip & ref \\
\hline 1 & $08 / 05 / 1939$ & 37.40 & -23.90 & 15 & $7.1 \mathrm{~s}$ & 199 & 41 & 35 & -154 & BUF \\
\hline 2 & $06 / 09 / 1964$ & 38.30 & -26.60 & 15 & $5.1 \mathrm{w}$ & 0.54 & 185 & 62 & 3 & BUF \\
\hline 3 & $04 / 07 / 1966$ & 37.50 & -24.70 & 10 & $5.5 \mathrm{w}$ & 1.90 & 341 & 49 & -42 & BUF \\
\hline 4 & $05 / 07 / 1966$ & 37.60 & -24.70 & 18 & $5.0 \mathrm{w}$ & 0.41 & 180 & 48 & 30 & BUF \\
\hline 5 & $20 / 04 / 1968$ & 38.30 & -26.60 & 15 & $4.6 \mathrm{w}$ & 0.09 & 117 & 42 & 89 & BUF \\
\hline 6 & $23 / 11 / 1973$ & 38.46 & -28.31 & 15 & $5.1 \mathrm{~s}$ & 2.0 & 23 & 90 & -179 & BUF \\
\hline 7 & $11 / 12 / 1973$ & 38.74 & -28.67 & 15 & $5.0 \mathrm{w}$ & 0.34 & 329 & 58 & -20 & BUF \\
\hline 8 & $01 / 01 / 1980$ & 38.81 & -27.78 & 7 & $6.8 \mathrm{w}$ & 190 & 149 & 85 & -2 & BOR \\
\hline 9 & $02 / 12 / 1981$ & 38.38 & -26.13 & 15 & $5.6 \mathrm{w}$ & 3.20 & 141 & 42 & -80 & CMT \\
\hline 10 & $09 / 09 / 1984$ & 36.93 & -24.60 & 12 & $5.3 \mathrm{w}$ & 0.95 & 178 & 37 & -79 & CMT \\
\hline 11 & $16 / 10 / 1988$ & 37.38 & -25.16 & 15 & $5.3 \mathrm{w}$ & 0.89 & 303 & 90 & 180 & CMT \\
\hline 12 & $21 / 11 / 1988$ & 38.34 & -26.27 & 15 & $5.9 \mathrm{w}$ & 7.10 & 345 & 29 & -37 & CMT \\
\hline 13 & $21 / 01 / 1989$ & 37.92 & -25.92 & 15 & $5.7 \mathrm{w}$ & 3.40 & 131 & 41 & -87 & CMT \\
\hline 14 & $26 / 06 / 1989$ & 39.11 & -28.32 & 15 & $5.8 \mathrm{w}$ & 5.40 & 105 & 32 & -110 & CMT \\
\hline 15 & $23 / 09 / 1989$ & 39.27 & -29.24 & 15 & $5.1 \mathrm{w}$ & 0.44 & 233 & 45 & -90 & CMT \\
\hline 16 & $09 / 12 / 1991$ & 37.22 & -23.61 & 15 & $5.2 \mathrm{w}$ & 0.82 & 330 & 45 & -90 & CMT \\
\hline 17 & $20 / 01 / 1993$ & 38.39 & -29.34 & 15 & $5.4 \mathrm{w}$ & 1.20 & 132 & 33 & -59 & CMT \\
\hline 18 & $09 / 03 / 1996$ & 37.13 & -23.85 & 15 & $5.7 \mathrm{w}$ & 3.80 & 319 & 28 & -106 & CMT \\
\hline 19 & $27 / 06 / 1997$ & 38.33 & -26.68 & 7 & $5.8 \mathrm{w}$ & 7.0 & 290 & 44 & -114 & BOR \\
\hline 20 & $27 / 06 / 1997$ & 38.26 & -26.16 & 15 & $5.2 \mathrm{w}$ & 0.62 & 284 & 27 & -147 & CMT \\
\hline 21 & $28 / 06 / 1997$ & 38.41 & -26.64 & 15 & $5.1 \mathrm{w}$ & 0.58 & 290 & 44 & -114 & CMT \\
\hline 22 & $09 / 07 / 1998$ & 38.65 & -28.63 & 7 & $6.0 \mathrm{w}$ & 14 & 153 & 85 & 6 & BOR \\
\hline 23 & $01 / 08 / 2000$ & 38.79 & -29.01 & 15 & $5.1 \mathrm{w}$ & 0.51 & 97 & 62 & -170 & CMT \\
\hline 24 & $30 / 11 / 2002$ & 39.25 & -28.45 & 15 & $5.1 \mathrm{w}$ & 0.52 & 106 & 45 & -129 & CMT \\
\hline 25 & $05 / 04 / 2007$ & 37.45 & -24.62 & 12 & $6.2 \mathrm{w}$ & 41 & 129 & 44 & -89 & CMT \\
\hline 26 & $04 / 11 / 2007$ & 37.40 & -24.39 & 12 & $6.0 \mathrm{w}$ & 11 & 133 & 44 & -87 & CMT \\
\hline
\end{tabular}

Table 1. Seismic events with published focal parameters for the Azores region (from 1900 to present). References: CMT: centroid-moment tensor, Havard in Borges et al. [2007, 2008], BUF: Buforn et al. [1988], BOR: Borges et al. [2007]. For the magnitude w and s indicate Mw e Ms, respectively [Borges et al. 2007, 2008].

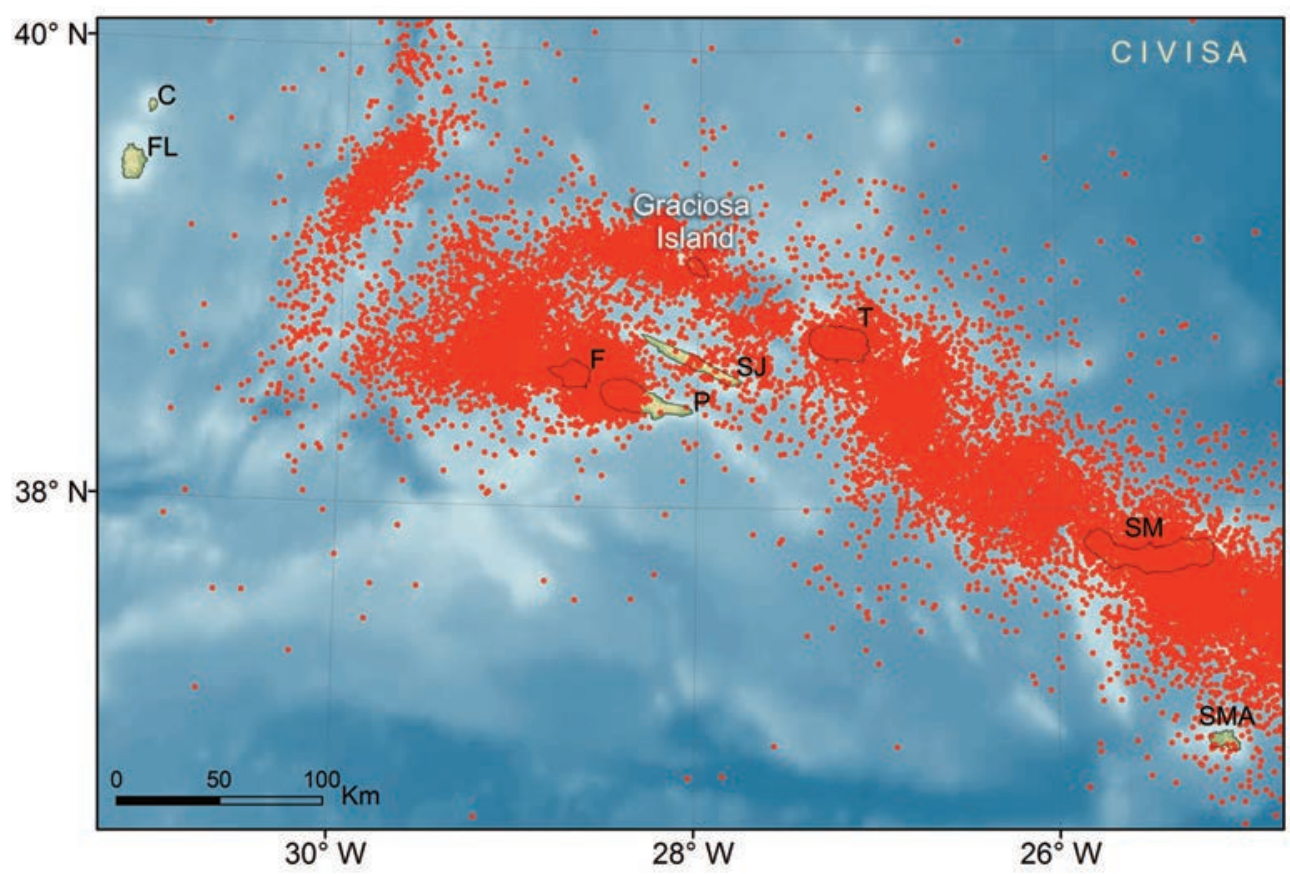

Figure 3. Seismicity in Azores region from 1980 to 2012. The red dots mark epicentres of earthquakes. Plot includes earthquakes of all magnitudes. Acronyms as in Figure 1. Data from CIVISA (Centro de Informação e Vigilância Sismovulcânica dos Açores), 2013. 
SW normal dextral faults, is incompatible with the regional stress field described above (Carmo [2004], Figure 2). This set of faults is ascribed to a different, previously unknown, stress field, characterized by horizontal E-W o1.

Due to this geodynamic setting, the Azores region is subject to active volcanism and frequent seismicity (Figure 3). The seismic activity is characterized by isolated seismic events and/or swarms of tectonic and/or volcanic nature, with shallow focal depths and low to moderate magnitudes. Moderate to high magnitude earthquakes, up to $M=7$, have also occurred in modern times (Table 1). Instrumental data present seismic events with variable focal mechanisms mainly indicating dextral (with WNW-ESE and NNE-SSW nodal planes) and sinistral, normal slip (with NW-SE trending nodal planes), oblique-slip, and a few reverse events [McKenzie 1972, Udías et al. 1976, Udías 1980, Hirn et al. 1980, Grimison and Chen 1986, Udías et al. 1986, Buforn et al. 1988, Moreira 1991, Mezcua et al. 1991, Miranda et al. 1998, Lourenço et al. 1998, Matias et al. 2007, Dias et al. 2007, Borges et al. 2007, 2008, Borges and Buforn 2008, Silva et al. 2012]. The instrumental seismicity recorded since the 1980's highlights the Eu-Nu plate boundary (Figure 3).

Graciosa Island was affected by a few significant earthquakes since settlement in mid-15th century, causing some deaths and severe damage (Table 2). Based on the historical descriptions of damages, some authors suggest that the epicentre of the January 21st, 1837 earthquake was on land [Madeira 1998, Silva 2005]. Instrumental seismicity in and around Graciosa is presented in Figure 4.

Graciosa has a NW-SE trending elliptical shape, 12 $\mathrm{km}$ long, $7 \mathrm{~km}$ wide and has a smooth relief reaching a maximum elevation of $402 \mathrm{~m}$. As in other volcanic islands of the Azores archipelago, the elongated morphology of Graciosa reflects the main tectonic trend of the Azorean segment of the Eu-Nu plate boundary and, more specifically, the NW-SE direction of the western sector of the Terceira Rift [Machado 1959], a tectono-magmatic structure defined by the alignment of alternating volcanic buildings (Graciosa and Terceira Islands, Banco Dom João de Castro seamount, and São Miguel Island) and tectonic basins (West and East Graciosa and North and South Hirondelle). The tectonic structure controlled most of the volcanic activity responsible for the build-up of the island. That is a common phenomenon that occurs in several oceanic volcanic islands independently of their geodynamic setting, such as the Fuerteventura and Lanzarote islands (Canary Islands) in which the elongation clearly

$\begin{array}{llll}\begin{array}{l}\text { Date } \\ (\mathrm{d} / \mathrm{m} / \mathrm{yr})\end{array} & \text { Intensity } & \text { Most affected area } & \text { Damage }\end{array}$

\begin{tabular}{|c|c|c|c|c|}
\hline$? / ? / 1611 / 36$ & - & Santa Cruz (?) & Santa Cruz Church & 4 \\
\hline ?/?/1717 & - & $\begin{array}{l}\text { Northern part of island } \\
\text { (Guadalupe and Santa Cruz villages) }\end{array}$ & Houses destroyed & 4,3 \\
\hline $13 / 6 / 1730$ & VII & $\begin{array}{c}\text { South part of island (Luz and Praia } \\
\text { villages) }\end{array}$ & Total destruction & 6 \\
\hline$? / 3 / 1787$ & - & - & - & 1 \\
\hline$? / 1 / 1817$ & - & - & - & 1 \\
\hline $21 / 1 / 1837$ & VII & $\begin{array}{l}\text { Central part of the island } \\
\text { (Guadalupe and Santa Cruz villages; } \\
\text { Caminho das Fontes and Almas) }\end{array}$ & $\begin{array}{c}\text { Houses destryed; } 3 \text { deaths; Probable } \\
\text { rupture along the South Serra das } \\
\text { Fontes Fault }\end{array}$ & 6.2 \\
\hline$? / ? / 1868$ & - & - & Houses damaged; Landslides & 1,5 \\
\hline $11 / 12 / 1883$ & - & - & - & 1 \\
\hline $19 / 2 / 1868$ & - & - & - & 1 \\
\hline
\end{tabular}

Table 2. Historical seismicity in Graciosa Island (Modified from Gaspar [1996]). References: 1. Moniz [1883], 2. Arquivo dos Açores [1890], 3. Matos [1982],, 4. Pereira [1986], 5. INMG/LNEC [1986], 6. Silva [2005]. 


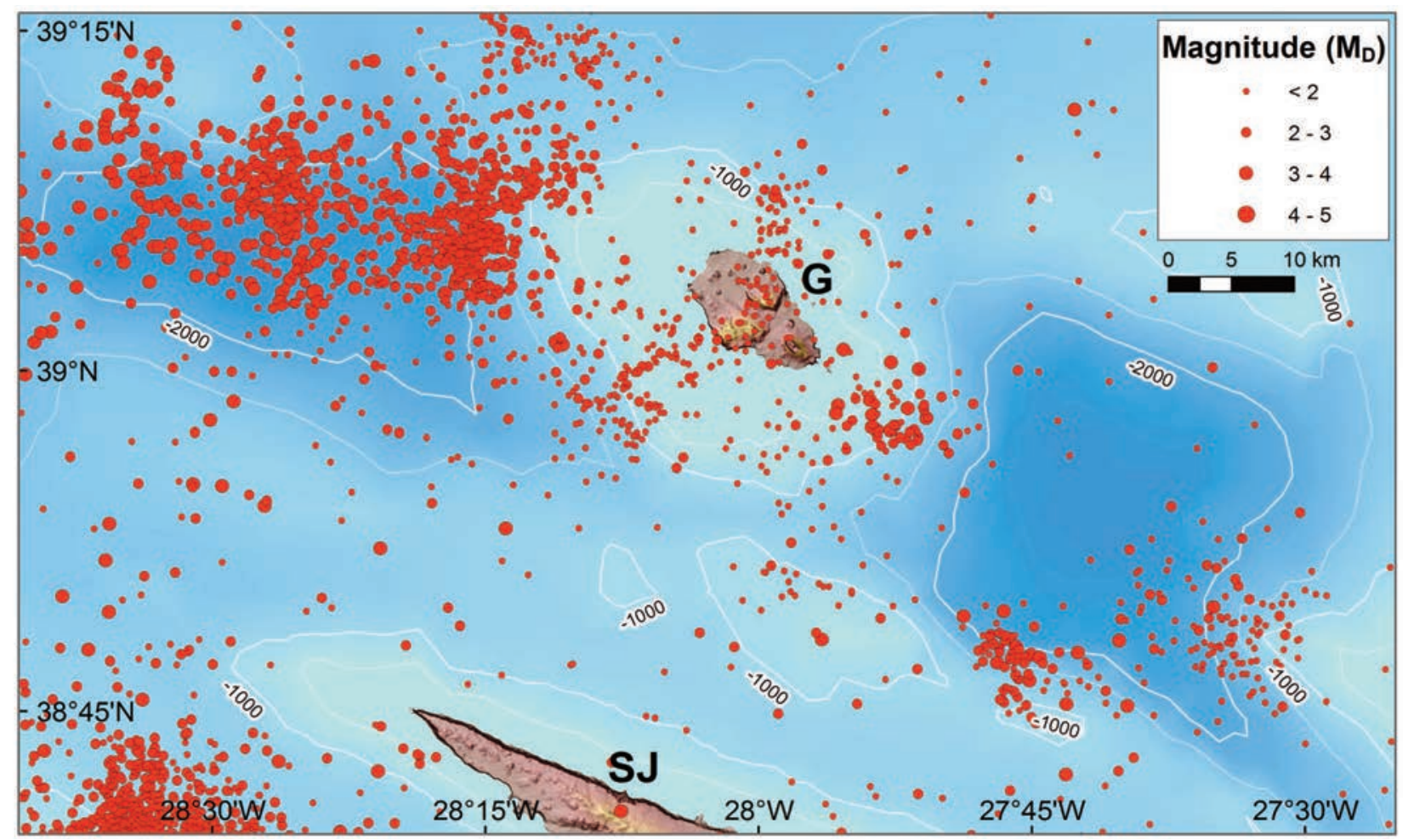

Figure 4. Seismicity in Graciosa region from 2002 to 2012. The red dots mark epicentres of earthquakes and its magnitude. Plot includes earthquakes of all magnitudes. G - Graciosa Island; SJ - São Jorge Island. Data from CIVISA (Centro de Informação e Vigilância Sismovulcânica dos Açores), 2012.

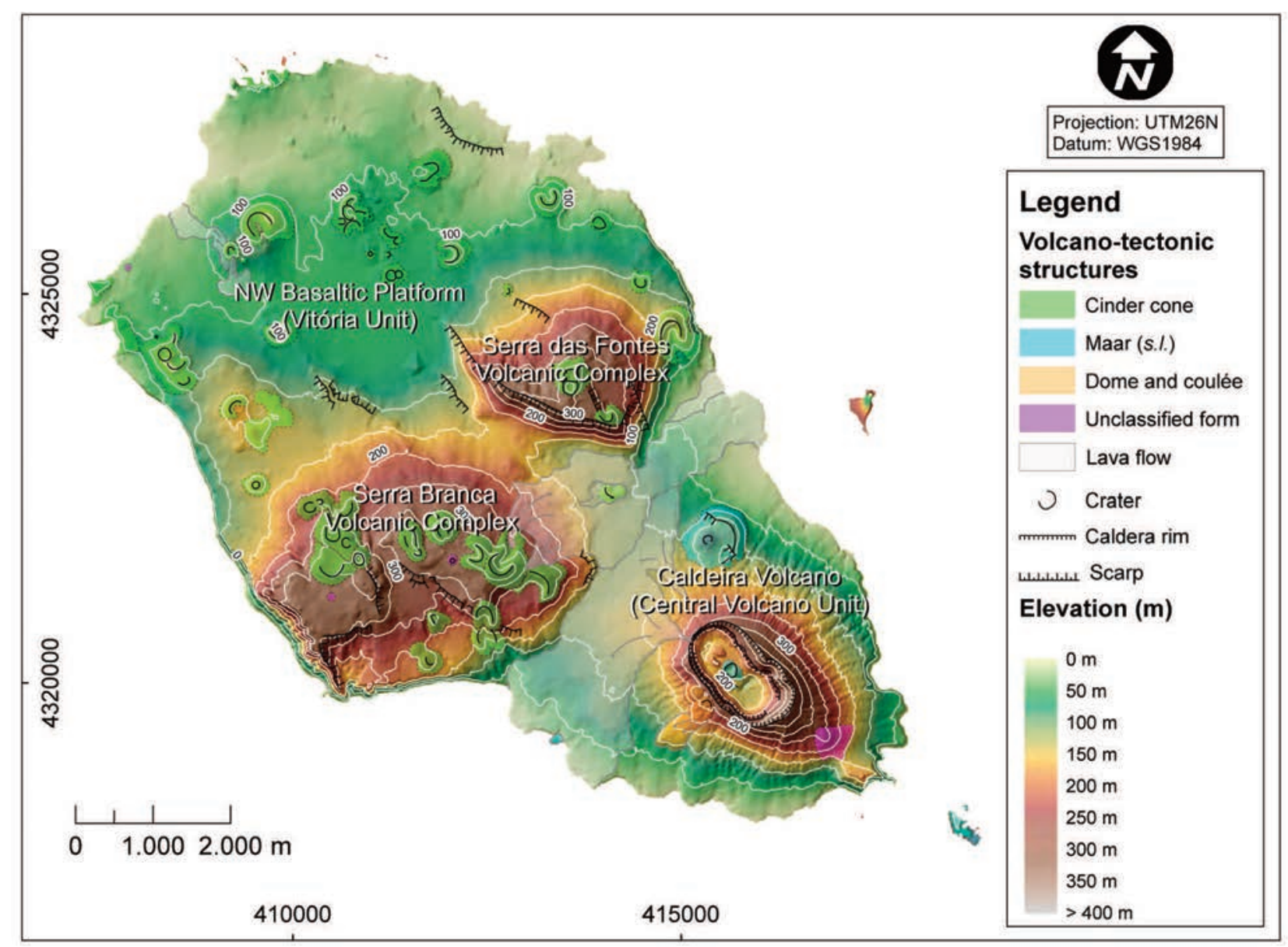

Figure 5. Three-dimensional elevation map of Graciosa Island. Main morphological structures and location of volcanic complexes. Topography from IGeoE [2001]. 
reflects the NNE-SSW trend of the East Canary Ridge [e.g. Camacho et al. 2001, Acosta et al. 2003].

The oldest volcano-stratigraphic units occupy the central part of Graciosa. They comprise the Serra das Fontes Volcanic Complex ( $620 \pm 120$ ka, Féraud et al. [1980]), a shield volcano composed of basaltic to mugearitic lavas, and the Serra Branca Volcanic Complex $(350 \pm 40 \mathrm{ka}$, Féraud et al. [1980]) a trachytic (sensu stricto) central volcano [Gaspar and Queiroz 1995, Gaspar 1996] (Figure 5). On the southeast sector a quiescent basaltic to trachytic (sensu lato) polygenetic volcano with a summit caldera constitutes the Central Volcano Unit (Caldeira Volcano) and in the northwest part of the island a low altitude plateau (the NW Basaltic Platform) is formed by alignments of basaltic cinder cones and the correlative lava flows forming the Vitória Unit [Gaspar 1996] (Figure 5). This fissural volcanic system extends to the southeast mantling the older volcanic complexes and developed simultaneously with the edification of the Caldeira Volcano. The two younger volcanic systems (Caldeira Volcano and NW Basaltic system) are Upper Pleistocene to Holocene in age. The most recent volcanic event was a pre-settlement basaltic hawaiian-strombolian eruption at about 2 ka B.P. (Walker, unpub- lished data, in Maund [1985]). Currently, the volcanic activity is expressed by secondary manifestations, namely by thermal springs, fumarole fields, and diffuse degassing [e.g. Ferreira et al. 1993, Gaspar 1996].

The older volcanic complexes (Serra das Fontes and Serra Branca) are displaced by several NW-SE trending faults morphologically expressed by large fault scarps parallel to the elongation of the island. Those faults define a graben structure that is crossed in its south-eastern portion by a NNE-SSW fault scarp, which separates the older units from the younger volcanic units to the south (Figures 6,7 ). The faults can be tracked into the younger volcanic areas where they express as volcanic alignments. The lack of surface ruptures displacing the younger units indicates that these structures present low slip-rates during the Holocene.

This work presents the first detailed structural analysis of Graciosa Island. The neotectonic data is used to discuss the relationship between geodynamic processes and the stress fields acting in the Azores region. They also contribute to define neotectonic parameters essential for seismic hazard assessment in order to estimate the seismogenic potential of active faults.

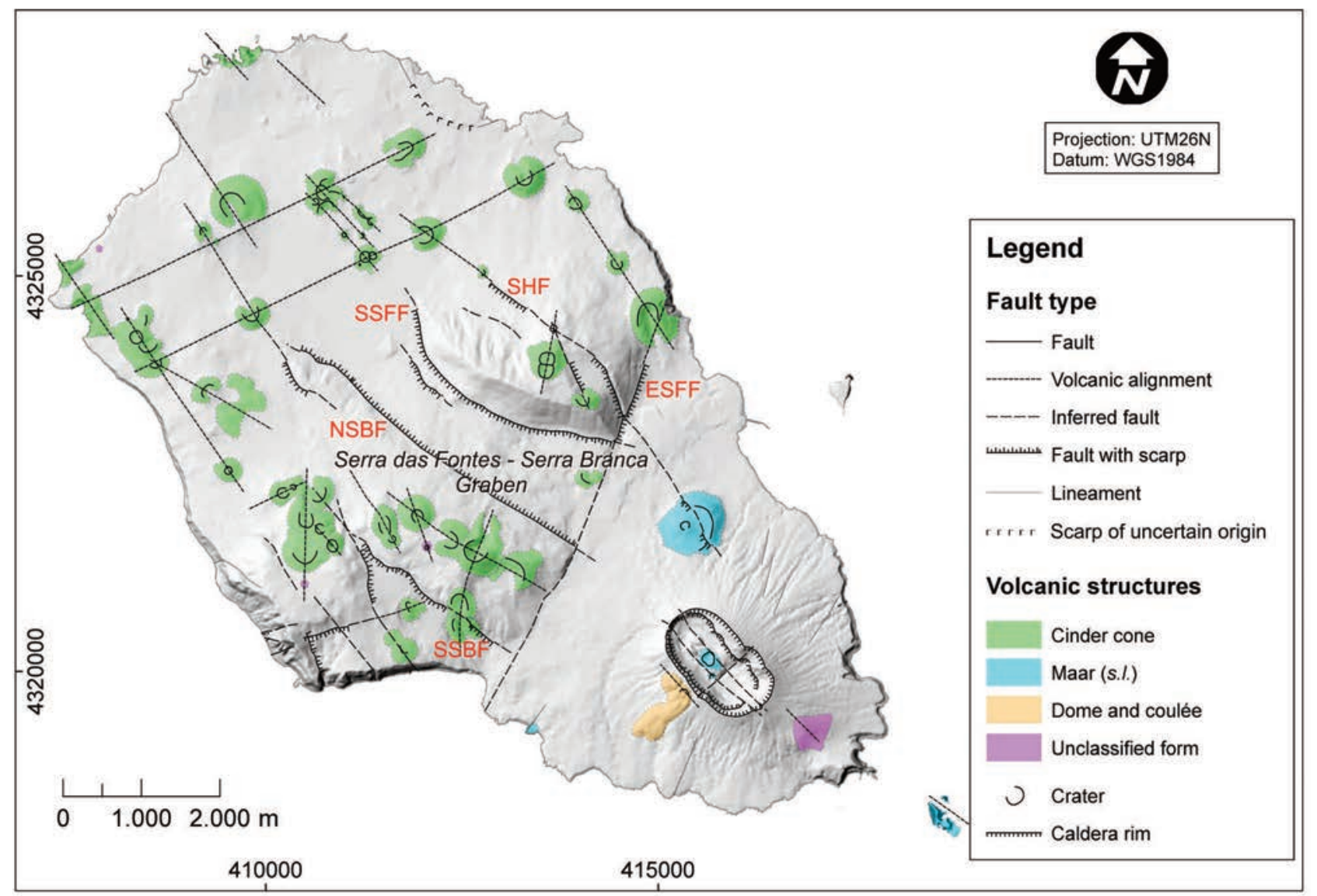

Figure 6. Morphotectonic map of Graciosa Island. Main tectonic structures: SHF - Saúde-Hortelã Fault; SSFF - South Serra das Fontes Fault; NSBF - North Serra Branca Fault; SSBF - South Serra Branca Fault; ESFF - East Serra das Fontes Fault. Topography from IGeoE (2001). 


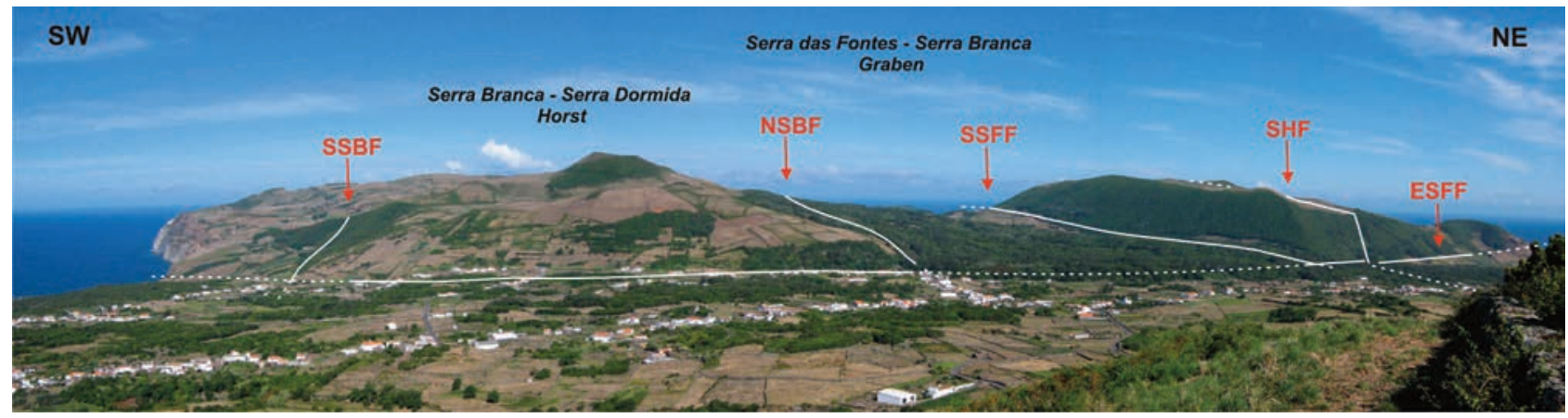

Figure 7. Photograph of fault scarps in the central region of Graciosa Island viewed from the SE. Continuous white lines indicate fault traces; dashed white lines mark hidden fault traces. Fault legend as in Figure 6.

\section{Data Acquisition}

In Graciosa neotectonic analysis is limited due to active volcanism that conceals the faults in significant areas of the island, reducing the available outcrops. Major tectonic features correspond to fault scarps several tens to hundreds of meters tall located in the central region of the island (Figures 6, 7). These structures extend into the younger volcanic regions as blind faults. The absence of detailed bathymetric surveys on the surrounding offshore precludes the reconnaissance of the full length of the faults. The large size of the fault scarps and the absence of recent surface faulting with favourable conditions for trenching preclude paleoseismological studies. The neotectonic data was collected mainly in cinder cone quarries (Figure 8) and at sea cliffs (Figure 9). The nature of the younger volcanic deposits, low-cohesion coarse lapilli and lava flows, is not favourable for the generation of slickensides, limiting kinematic analysis.

The mapped structures are normal faults or present a normal component. The kinematics were deduced from the displacement of morphologic and stratigraphic markers, and wherever possible, from striated fault planes. Although in most cases it was difficult to recognize a strike-slip component, a few structures present dextral or sinistral strike-slip components typical of a transtensile tectonic regime. Part of the amount of dip-slip offsets may be apparent and be the result of a strike-slip component displacing inclined surfaces.

A preliminary structural mapping was based on vertical air photo-interpretation and DEM (digital elevation model) and topographic map analysis, allowing recognition of morphologic features with probable tectonic origin (fault scarps) or tectonically controlled (e.g. cone or dome alignments, elongated craters, displaced or linear stream channels, linear sea cliffs). The tectonic nature of the identified alignments was confirmed or infirmed through detailed analysis of the outcrops. A total of 177 fault planes were measured and analyzed, including faults of variable importance cropping out in sea cliffs, small scale faults in cinder cones, and map-

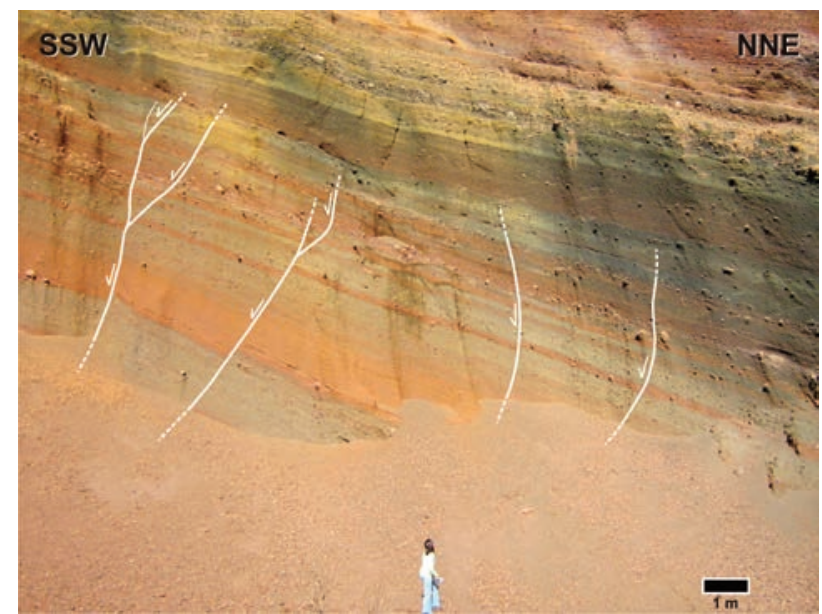

Figure 8. Small faults exposed on wall of a quarry exploiting lapilli from a cinder cone. White arrows specify the dip slip-vector.

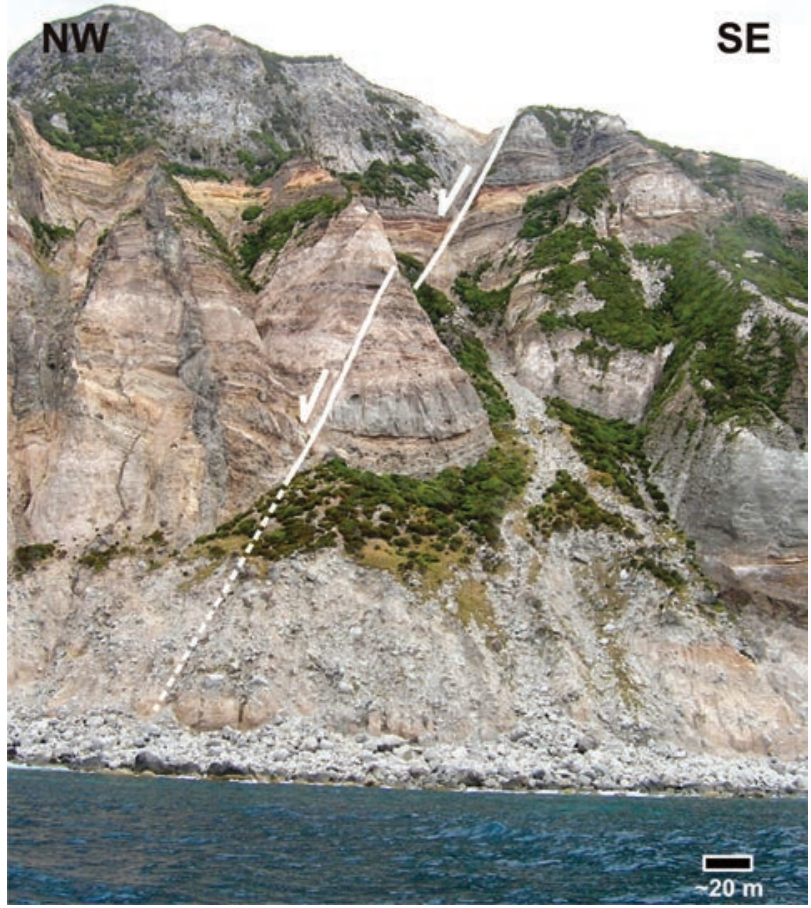

Figure 9. Example of a fault trace exposed in a sea cliff south of Serra Branca. Legend as in Figure 8. 
scale structures deduced from geological mapping. The structural map was later converted to a digital format, at the 1:25 000 scale (from IGeoE altimetry), using a GIS software. The structural data was included in the AZORIS data base [Gaspar et al. 2004].

\section{Structural data}

\subsection{Geometric and kinematic fault analysis}

The geometric analysis shows a main set of faults trending NW-SE to NNW-SSE, dipping to NE and SW or to ENE and WSW, respectively (Figure 10). This set of structures includes the larger structures expressed morphologically as fault scarps. The main NW-SE trending structures are the South Serra das Fontes Fault (SSFF), the Saúde - Hortelã Fault (SHF), the North Serra Branca Fault (NSBF), and the South Serra Branca Fault (SSBF) (Figures 6, 7). The SSFF presents a slightly convex, 4600m-long and 150-200m-high southwest-facing scarp, trending ca. N306 ${ }^{\circ}$. To the north this structure is marked by an alignment of four basaltic cinder cones. The SHF trace is marked by a $5000 \mathrm{~m}$-long, less than $10 \mathrm{~m}$-high south-facing scarp, trending ca. N320 from Pico da Hortelã to Pico da Ladeira do Moiro cones, producing $50 \mathrm{~m}$ of dextral strike-slip displacement at the intersection with the East Serra das Fontes Fault (ESFF) scarp. The NSBF presents a $4800 \mathrm{~m}$-long northeast-facing scarp, trending $\mathrm{N} 302^{\circ}$, which is aligned with two cones of the NW Basaltic Platform and to the southeast with the long axis of the Caldeira Volcano. The SSBF scarp faces southwest, trends $\mathrm{N} 305^{\circ}$, and may control the location of some basaltic cones to the northwest. These faults define a graben structure in the centre of Graciosa, the Serra Branca - Serra das Fontes Graben, south of which the NSB and SSB faults define a horst (Figures 6, 7). The total length of these faults is unknown because on land they are locally concealed beneath younger lava flows, pyroclastic and/or epiclastic deposits, and there is no offshore data to assess its extension in the seafloor. A second set of faults trend NNE-SSW to NE-SW and dip to the SE and NW (Figure 10). It is represented by small-scale structures cropping out in cinder cones, by cone alignments, and by a major NNE-SSW trending structure, the ESFF (Figures $6,7)$. The $N 20^{\circ}$ trending ESFF trace is marked by a $4600 \mathrm{~m}$-long and $185 \mathrm{~m}$ tall southeast facing scarp. Inside the Caldeira Volcano there is a volcanic lineament trending NE-SW (Figure 6). E-W trending faults, although less frequent, also occur. In addition to the observed faults, some morphological features evidence similar trend, such as two ENE-WSW cinder cones alignments in the NW Basaltic Platform, or a rectilinear sea cliff south of Serra Branca, suggesting an E-W tec- tonic control (Figure 6). Gaspar [1995, 1996] proposes that E-W faults are inherited from the oceanic basement on which the islands stand (old transform faults). E-W trending faults were also described by Madeira [1998] in the islands of São Jorge, Faial, and Pico. Moreover, the presence of $\mathrm{E}-\mathrm{W}$ trending structures crossing the Azores Plateau is mentioned by Searle [1980].

The geometric and kinematic fault analyses show that the NW-SE trending, SW-dipping faults, present normal-dextral or dextral-normal oblique slip. Oblique normal-left lateral or left lateral-normal slip was observed in NNE-SSW to NE-SW trending, SE to ESEdipping faults, and normal-dextral or dextral-normal oblique slip in NNE-SSW to NE-SW faults dipping to WNW and NW. Despite the limited number of faults presenting evidence of oblique displacement (strike-slip associated to normal component), the kinematic data obtained from field observations in Graciosa Island suggest a transtensive tectonic regime evidencing three-dimensional strain [Reches 1983, Reches and Dieterich 1983], in agreement with the tectonic pattern described in previous works in other Azorean islands [e.g. Madeira 1986, Madeira and Ribeiro 1990, Madeira 1998, Madeira and Brum da Silveira 2003, Carmo 2004]. Hence, kinematic data from Graciosa indicate the existence of two main fault systems (Figure 11). System A is composed of two sets of conjugated faults, one trending NW-SE, dipping to SW and NE, presenting normal-dextral or dextral-normal oblique slip, and another striking NNE-SSW, dipping to ESE and WNW, with oblique normal-left lateral or left lateral-normal slip (Figure 11a). System B includes NNE-SSW to NESW trending faults, dipping to WNW to NW or to ESE, presenting normal-dextral or dextral-normal oblique slip (Figure 11b). A family of faults conjugated with these structures was not found. The steep fault dips (the $80^{\circ}$ to $90^{\circ}$ range dominates) also suggest the presence of a strike-slip component (Figures 10b-11).

\subsection{Geometric dyke analysis}

Several dykes, both of basaltic and trachytic nature, were observed at the sea cliffs cutting the Serra das Fontes and Serra Branca volcanic complexes and the Caldeira Volcano. In the first case the dykes' directions are similar to the main fault systems, with two main trends, NNW-SSE and NE-SW, attesting for the tectonic control of the magmatic phases (Figure 12). The dyke system exposed on the sea cliffs cut on the Caldeira Volcano, represented by NE-SW trending dykes on the northeast flank and NW-SE dykes on the southeast, although scarce, suggests a radial pattern around the volcanic edifice (Figure 13). However, NNW-SSE trending dikes occurring in the southeast 


\section{GRA Total faults}
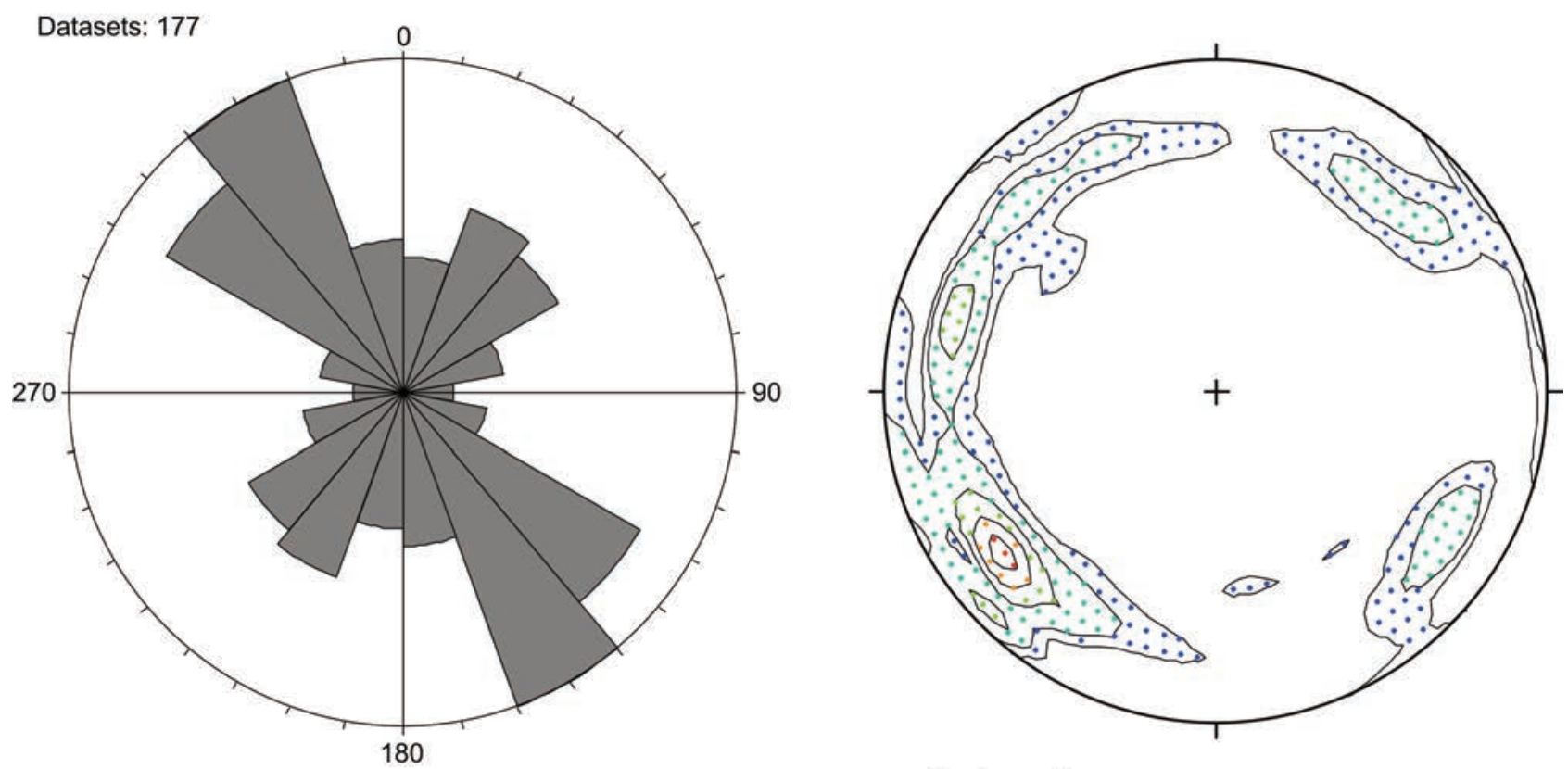

ᄅ) $\begin{aligned} & \text { Interval: } 20^{\circ} \\ & \max =22.03 \%\end{aligned}$

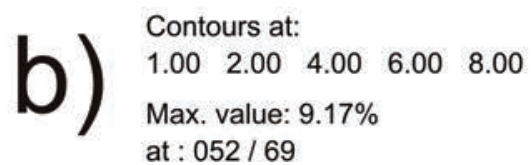

Figure 10. Geometry of all analyzed faults: a) Circular histogram of unweighted frequencies of fault plane directions; b) fault poles density contour plot (lower hemisphere; Schmidt net); TectonicsFP software ${ }^{\circledR}$ [Ortner et al. 2002].
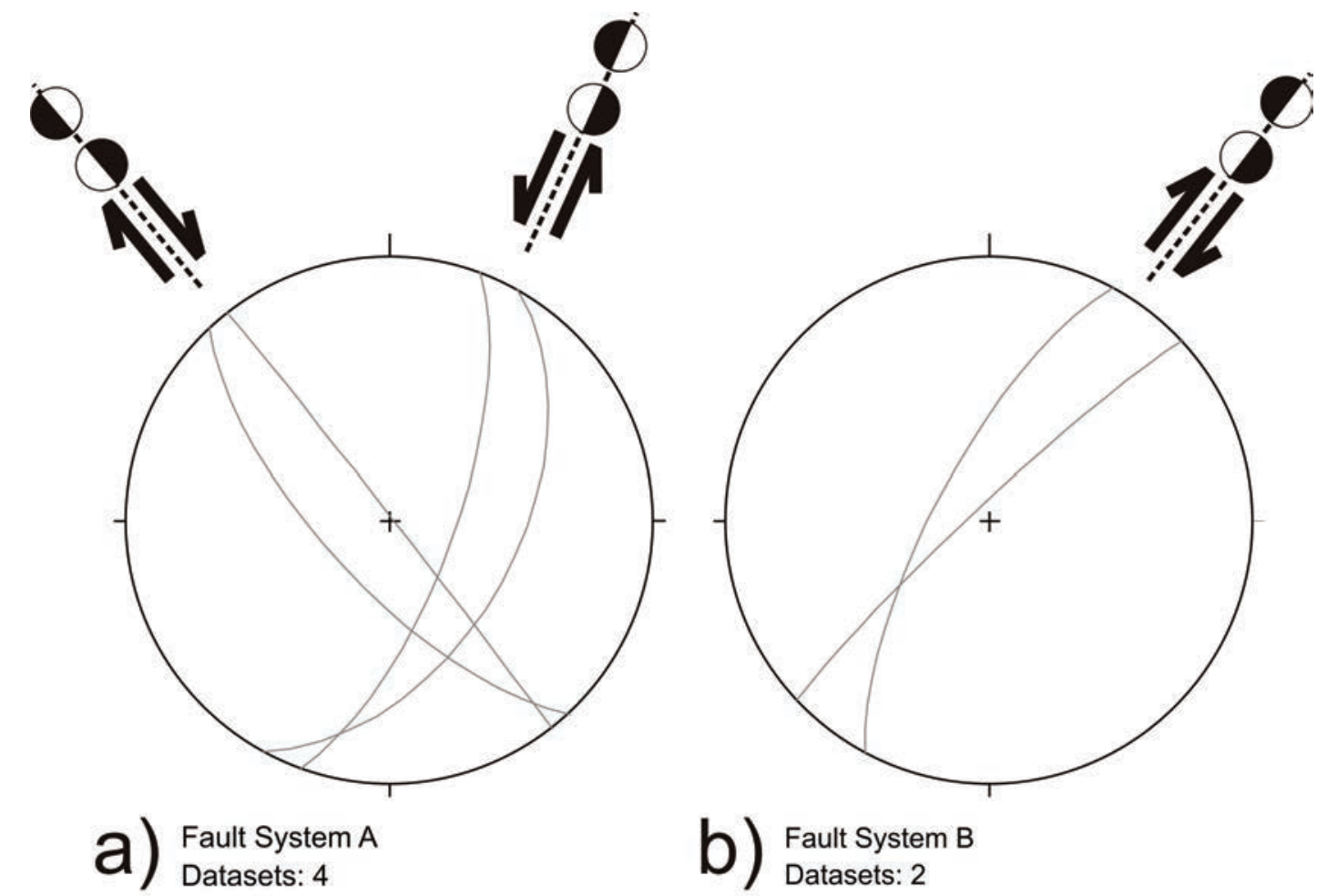

b) Fault System B
Datasets: 2

Figure 11. Stereographic plot of the two main fault systems (lower hemisphere; Schmidt net - $\beta$ diagram): a) system A - NW-SE to NNWSSE faults, with normal-dextral oblique slip, conjugate of NNE-SSW to NE-SW normal-left lateral structures; b) system B - NNE-SSW to NE-SW faults with normal-dextral oblique slip. TectonicsFP software ${ }^{\circledR}$ [Ortner et al. 2002].

coastal cliffs are not in agreement with a radial pattern and may represent en echelon dykes consistent with
NW-SE dextral shearing compatible with the kinematics of fault System A, implying a magmatic phase con- 


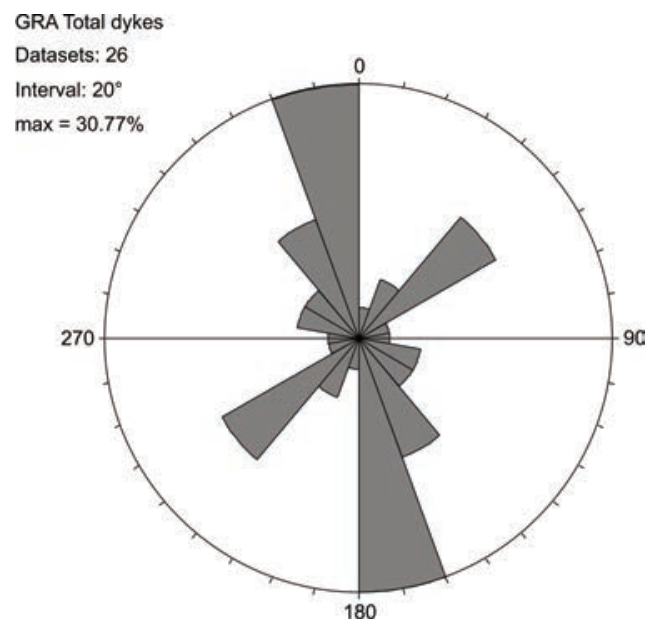

Figure 12. Geometry of all measured dykes: a) Circular histogram of unweighted frequencies of dykes' plane directions. TectonicsFP

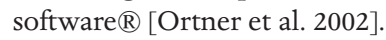

trolled by ENE-WSW crustal extension. Note that, because of three-dimensional strain, transtensional faults may act as volcanic conduits, so dykes are not necessarily normal to the direction of extension (i.e. they may open obliquely to the fracture direction). This is attested by the fact that in many Azorean islands, alignments of monogenetic centres are mostly parallel to the fault system synthetic with the plate boundary, but alignments along the conjugate direction also occur.

\section{Discussion}

\subsection{Determining paleostress}

The two main fault systems (A and B) are incompatible with a single stress field. None of the fault systems is exclusive of a given volcanic system; they affect all stratigraphic units and may occur together. This indicates that the different stress fields are neither related to a given period of time nor related to deformation associated to a particular volcanic centre. The paleostress analysis indicates the presence of two different stress fields. The stress field \#1, associated to the fault system A, presents horizontal NNW-SSE $\sigma 1$ (maximum compressive stress axis; Anderson 1951; Angelier 1994), horizontal ENE-WSW $\sigma 3$ (maximum tensile stress axis) and a vertical intermediate compressive stress axis ( $\sigma 2)$. Permutations between $\sigma 1$ and $\sigma 2$ may occur producing alternating transtensile and tensile tectonic regimes [Madeira 1998] (Figure 14). The stress field \#2, related to the fault system $\mathrm{B}$, is characterized by horizontal WSW-ENE $\sigma 1$, horizontal NNW-SSE $\sigma 3$ and vertical $\sigma 2$. Permutation may also occur between $\sigma 2$ and $\sigma 1$ following events of stress drop during transtensile phases (Figure 15). Because the two different stress fields cannot operate simultaneously, and since they are not local stress fields, they must alternate in time, generating new faults or reactivating pre-existing structures. The spatial-tem-

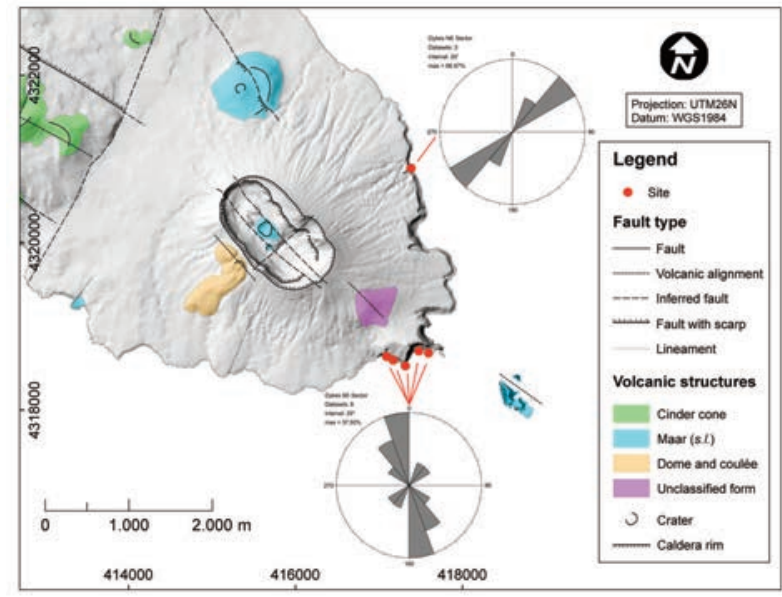

Figure 13. Spatial variations of dyke directions around Caldeira Volcano (circular histograms of unweighted frequencies of dyke directions and dip angles). Topography from IGeoE (2001).

poral relation between the two stress fields is unclear.

The stress field \#1 agrees with the findings of Madeira and Ribeiro [1990] for the Azores Plateau and with the geodynamic model proposed by Madeira [1998] and Lourenço et al. [1998] for the Azorean segment of the Eu-Nu plate boundary. It considers the occurrence of a rotation to N-S and E-W of $\sigma 1$ and $\sigma 3$, respectively, closer the edges of the shear zone, as observed in Santa Maria Island [Madeira 1986], (Figure 2). The maximum tensile stress axis direction is also in agreement with the opening direction according the current kinematic plate models for the relative Eu-Nu motion (e.g. N66 ${ }^{\circ}$ NUVEL-1A, DeMets et al. 1994; N80'-REVEL, Sella et al. 200; N72 ${ }^{\circ}$-DEOS2K, Fernandes et al. 2006; N71 ${ }^{\circ}$ MORVEL, DeMets et al. 2010; Table 3).

The stress field \#2 is probably external to the shear zone and may temporarily affect the areas at the border of the shear zone, since it is also found in the eastern part of São Miguel Island [Carmo 2004]. The width of the shear zone accommodating the deformation between $\mathrm{Eu}$ and Nu may change proportionally to the difference between the NA-Eu and NA-Nu spreading rates, north and south of the triple junction, respectively. Narrowing of the area under the influence of the regional stress field \#1 (i.e. the shear zone) would put the margins of that sheared region temporarily under the influence of the outer transtensile stress field \#2.

Two hypothesis are considered for the origin of the stress field \#2: (1) the existence of an intermediate region under transtension, developing parallel to the MAR and establishing a transition zone between the pure tensile stress field at the MAR and the distal compressive stress field, established as the sea-floor moves away from the ridge (Figures 16-Ia-16-Ib); (2) the existence of an intermediate region, with a transtensile regime, defining a narrow band between the interplate region with dextral transtension (stress field \#1) and the external compres- 


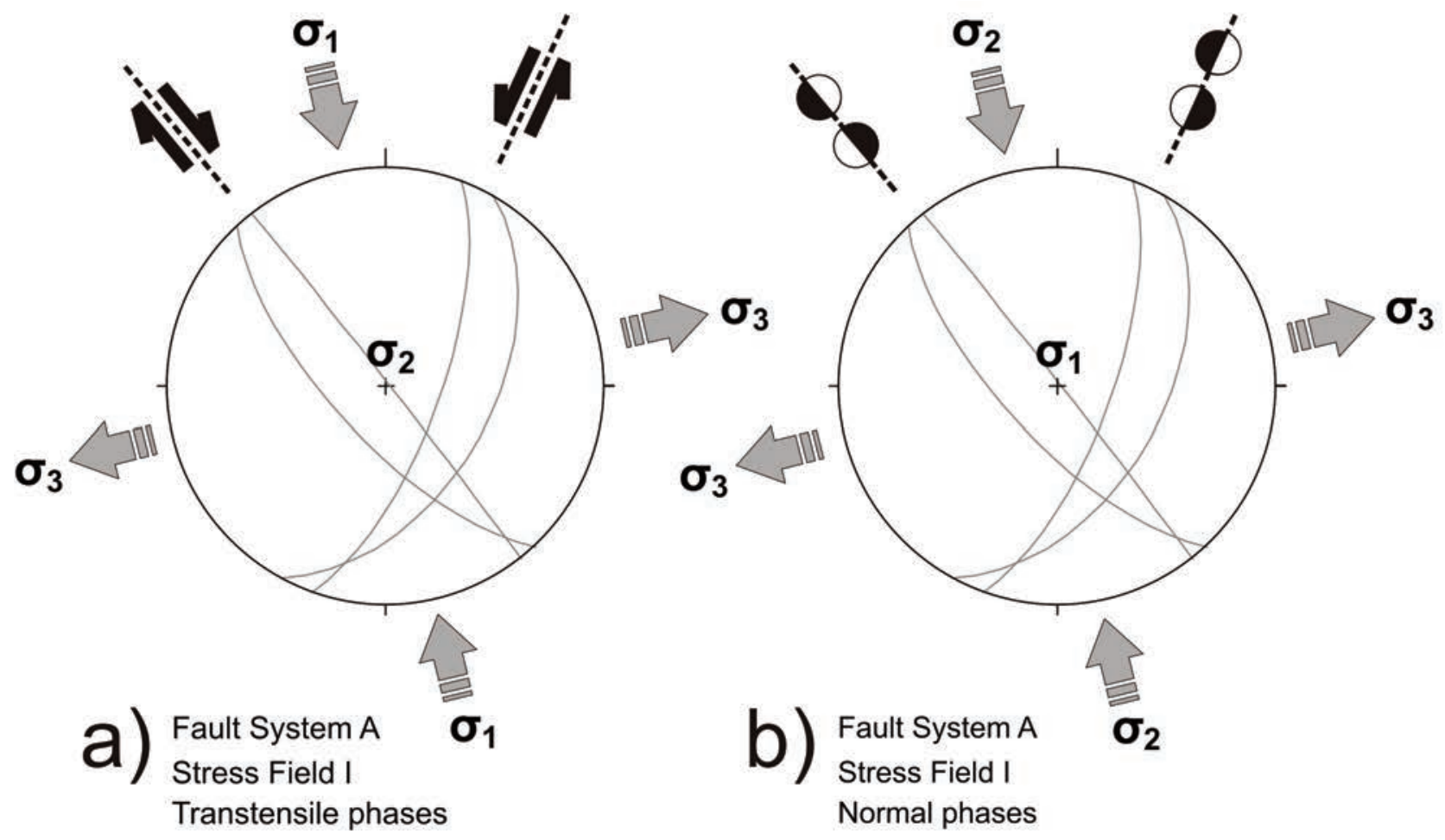

Figure 14. Stereographic projection of the stress field \#1 deduced from structures of fault system A that have kinematic data of both slip components (lower hemisphere; Schmidt net $-\beta$ diagram). a) transtensile stress field: NW-SE to NNW-SSE faults with dominant dextral slip component, conjugate of NNE-SSW to NE-SW structures with dominant left-lateral slip component. Horizontal NNW-SSE $\sigma 1$, horizontal ENE-WSW $\sigma 3$ and vertical $\sigma 2$; b) tensile stress field after permutation between $\sigma 1$ and $\sigma 2$ : NW-SE to NNW-SSE faults, dipping to both sides, with dominant normal slip component conjugate of NNE-SSW to NE-SW faults, dipping to both sides, with dominant normal slip component. Vertical $\sigma 1$, horizontal ENE-WSW $\sigma 3$ and horizontal NNW-SSE $\sigma 2$. TectonicsFP software ${ }^{\circledR}$ [Ortner et al. 2002].
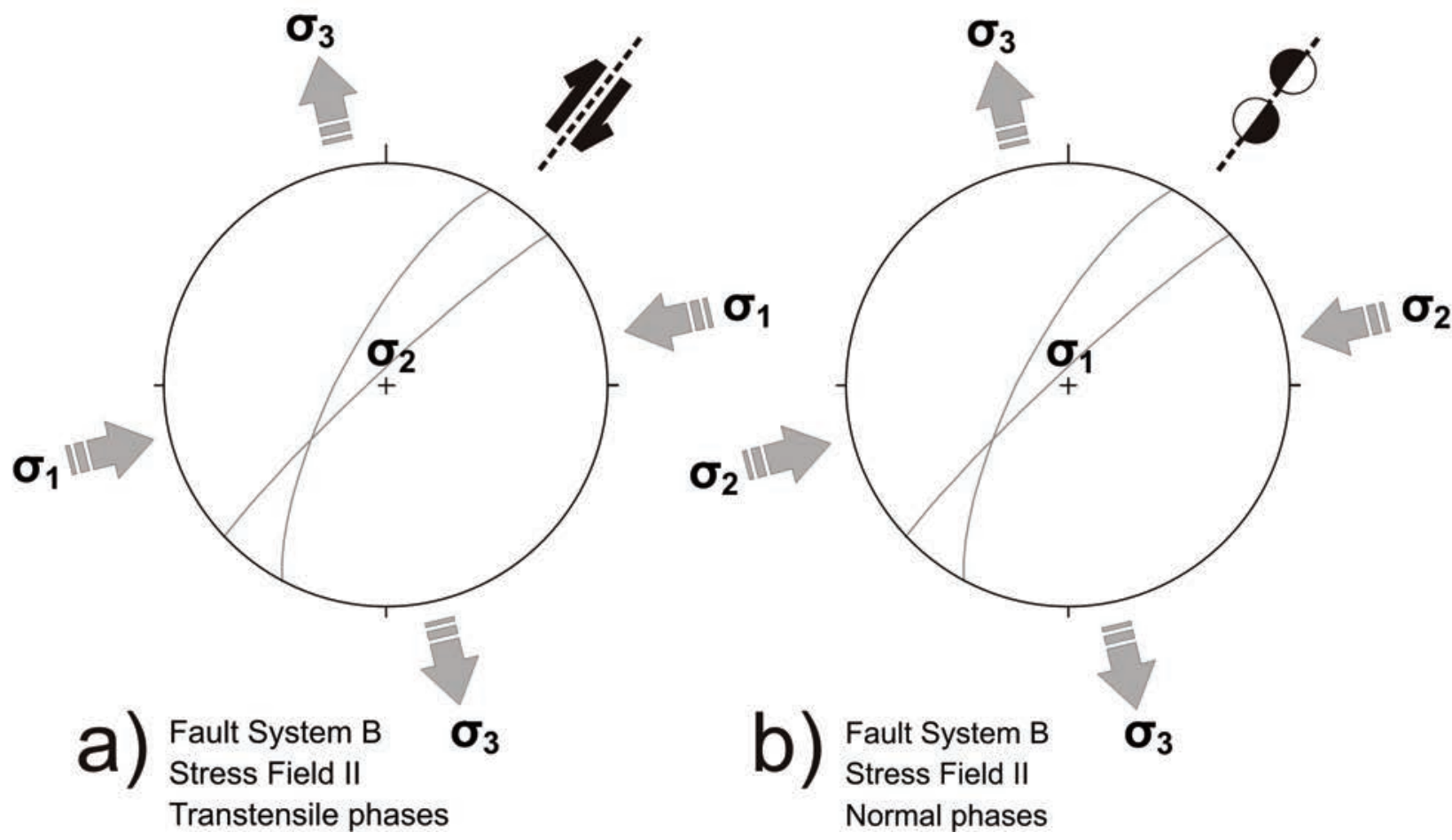

Figure 15. Stereographic projection of the stress field \#2 deduced from structures of fault system B that have kinematic data of both slip components (lower hemisphere of Schmidt net - $\beta$ diagram). a) transtensile stress field: NNE-SSW to NE-SW faults with dominant dextral slip component. Horizontal ENE-WSW $\sigma 1$, horizontal NNW-SSE $\sigma 3$ and vertical $\sigma 2$; b) tensile stress field after permutation between $\sigma 1$ and б2: NNE-SSW to NE-SW faults, dipping to both sides, with dominant normal slip component. Vertical $\sigma 1$, horizontal NNW-SSE $\sigma 3$ and horizontal ENE-WSW o2. TectonicsFP software ${ }^{\circledR}$ [Ortner et al. 2002]. 


\begin{tabular}{lccc}
\hline Plate pairs & Velocity $(\mathbf{m m} / \mathbf{a})$ & Azimuth $($ degrees $)$ & Kinematic model \\
\hline & $\sim 23$ & $\sim 97^{\circ}$ & NUVEL-1A \\
Eu-NA(stable) & $\sim 25$ & $\sim 96^{\circ}$ & REVEL \\
& $\sim 24$ & $\sim 94^{\circ}$ & DEOS2K \\
& $\sim 23$ & $\sim 96^{\circ}$ & MORVEL \\
& $\sim 20$ & $\sim 103^{\circ}$ & NUVEL-1A \\
Nu-NA(stable) & $\sim 19$ & $\sim 151^{\circ}$ & REVEL \\
& $\sim 19$ & $\sim 99^{\circ}$ & DEOS2K \\
& $\sim 20$ & MORVEL \\
Eu-Nu(stable) & $\sim 4$ & $\sim 66^{\circ}$ & NUVEL-1A \\
& $\sim 6$ & $\sim 72^{\circ}$ & REVEL \\
& $\sim 4$ & $\sim 80^{\circ}$ & DEOS2K \\
\hline
\end{tabular}

Table 3. Relative velocities and slip directions for $\mathrm{Eu}, \mathrm{Nu}$, and NA plates in Azores. Global kinematic models: NUVEL-1A [DeMets et al. 1994], REVEL [Sella et al. 2002], DEOS2K [Fernandes et al. 2003], MORVEL [DeMets et al. 2010].

I a)

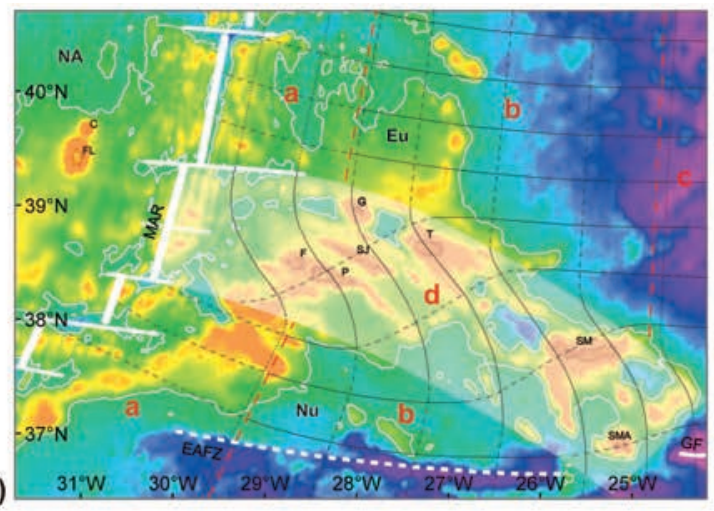

I b)
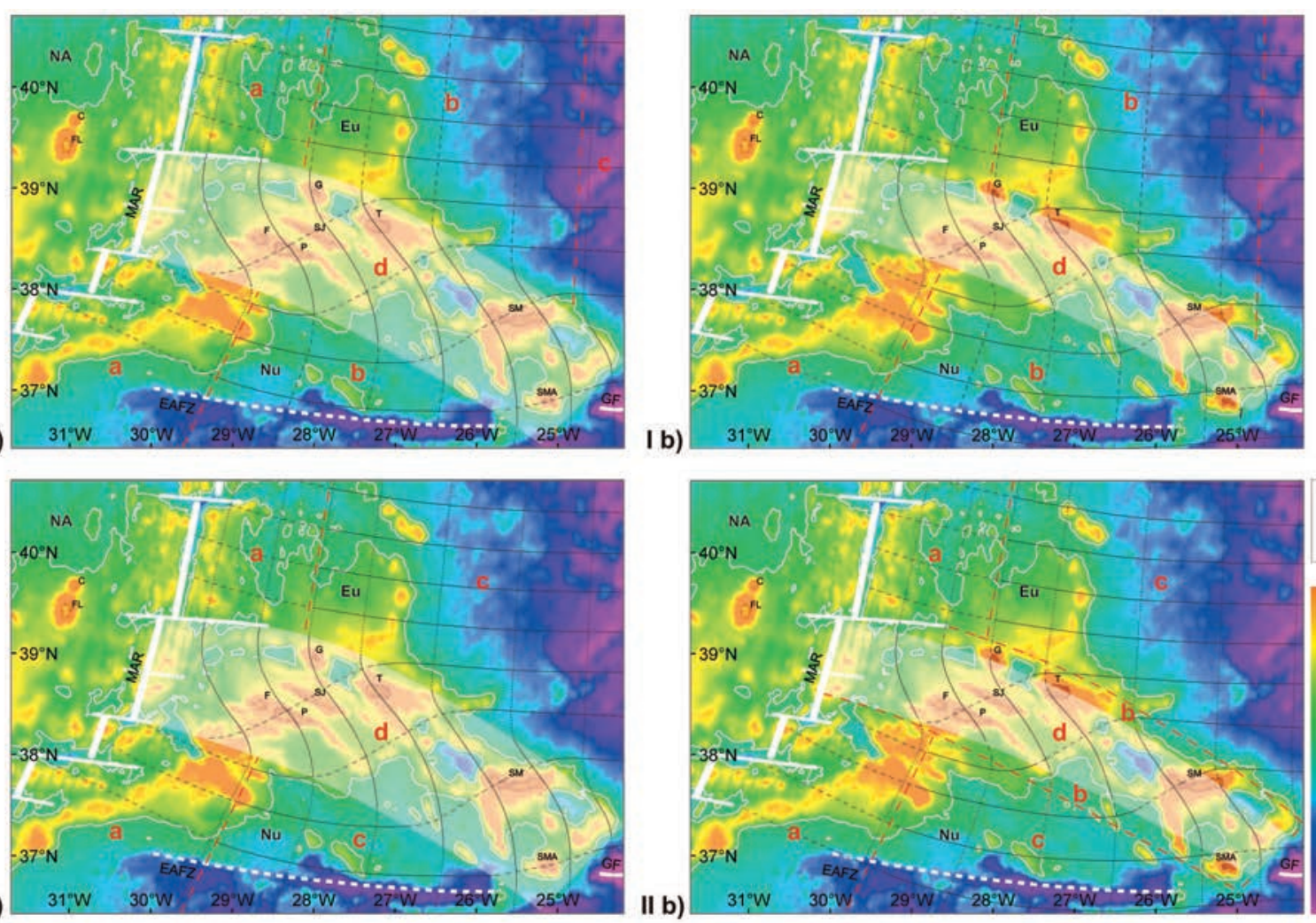

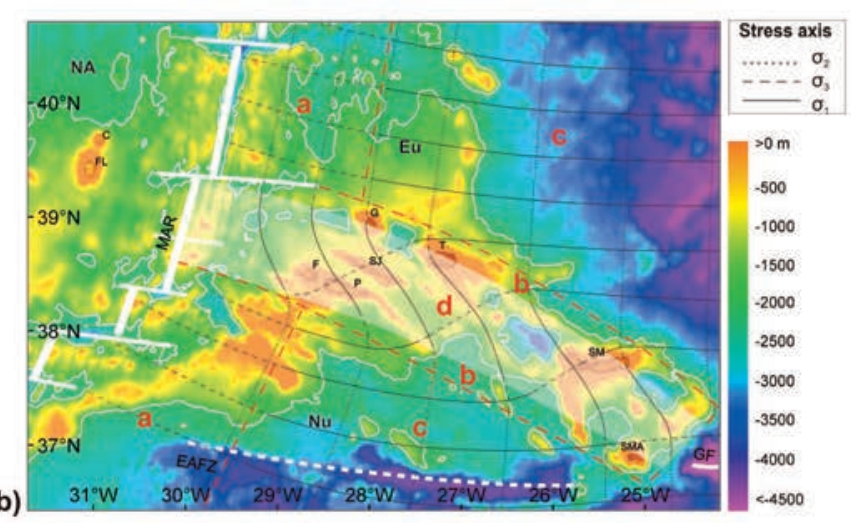

Figure 15. Estimated trajectories of the main stress axis in the western segment of the Eu-Nu plate boundary. Above - hypothesis (1): the tensile stress field (a) close to the MAR passes laterally to transtensive (b) with the establishment of a transition stress field. Eastward, further away from the ridge, permutation of $\sigma 3$ with $\sigma 2$ occurs as a region in compression is entered (c). Inside the sheared region (d) stress permutation and deviation of stress trajectories occur. Ia) Stages of widened shear zone; Ib) Stages of narrowed shear zone: the islands near the edges of the sheared interplate region are subjected to the stress field b. Below - hypothesis (2): the tensile stress field (a) close to the MAR passes laterally to compressive (c) as the sea-floor moves away from the ridge. Inside the sheared region (d) stress permutation and deviation of the stress trajectories occur. During stages of narrowing of the sheared region, permutation between $\sigma 2$ and $\sigma 3$ may originate a local intermediate stress field (b). IIa) Stages of widened shear zone; IIb) Stages of narrowed shear zone: the islands near edges of the sheared interplate region are subjected to the stress field $\mathrm{b}$. Red dashed lines separate the different stress field domains; white shaded area represents the interplate sheared region. Trajectories of maximum tensile stress axis near the MAR are based on the spreading direction of NA-Eu according to the NUVEL-1A (DeMets et al. 1994). Trajectories of the main stresses within the sheared zone are based on neotectonic data from emerged areas [e.g. Madeira and Brum da Silveira 2003, Carmo 2004, Hipólito 2009, and the present work]. Acronyms as in Figure1. Bathymetry adapted from Lourenço et al. [1997]. Datum: WGS 1984. 


\begin{tabular}{|c|c|c|c|c|c|}
\hline \multirow{2}{*}{ Structure } & \multicolumn{2}{|c|}{ Separation $(\mathbf{m})$} & \multirow{2}{*}{$\begin{array}{c}\text { Age of marker } \\
(\text { ka BP })\end{array}$} & \multicolumn{2}{|c|}{ Slip-rates $(\mathrm{mm} / \mathrm{a})$} \\
\hline & Dip-slip & Strike-slip & & Dip-slip & Strike-slip \\
\hline SHF & - & 50 & ca. $620-31.4$ & - & $0.08-1.6$ \\
\hline SSF & 200 & - & ca. $620-31.4$ & $0.3-6.4$ & - \\
\hline ESFF & 185 & - & ca. $620-31.4$ & $0.3-5.9$ & - \\
\hline
\end{tabular}

Table 4. Slip-rates for Graciosa faults.

sive stress field established as the sea-floor moves away from the ridge. The intermediate region would be established when the interplate shear stress is weaker (Figures $16,16,2 \mathrm{a}, 2 \mathrm{~b})$.

The E-W trending faults may reflect former deep transform faults cutting the ocean floor generated at the MAR (Gaspar 1995; 1996) that, because of a favourable direction, were later reactivated by the current dextral transtensile stress regime, probably as shear fractures ( $\mathrm{P}$ fractures, considering the Riedel shear model; e.g. Petit 1987).

\subsection{Insights on the seismogenic potential of Graciosa} faults

The available data do not provide enough information to carry out an assessment of seismic hazard associated to the identified structures. Nevertheless, the determination of neotectonic parameters such as the slip-rate is essential to define potential seismogenic sources in a given area, which will be helpful for a future detailed seismic hazard analysis.

Only three tectonic structures allowed slip-rate estimation: the SHF, the SSFF and the ESFF (Figure 6, 7). However, none of these structures allowed the determination of the total slip (normal slip and strike-slip components) along the fault over the considered time period. In two of them only the normal slip offset was determined, while in the other only the strike-slip could be measured. Given that dated stratigraphical markers only exist for the base of the volcano-stratigraphic units, we consider that the observed deformation accumulated during the $620 \pm 120 \mathrm{ka}$ to $31.4 \pm 0.3$ $\mathrm{ka}$ interval. This time interval corresponds to the oldest ages obtained for the Serra das Fontes Volcanic Complex and for the Caldeira Volcano / NW Basaltic Platform Complex, respectively [Féraud et al. 1980, Maund 1985], since the younger volcanic units are not tectonically displaced by those structures.

The estimated slip-rates are of the order of tenths of a millimetre to few millimetres per year (Table 4). These values are of the same magnitude as those provided by plate motion kinematic models for the whole archipelago, considering the Eu-Nu relative motion (Table 3). The higher slip-rates could be over-estimated because the age of the younger marker may not represent the end of the deformation period. On the other hand, the beginning of the tectonic deformation affecting the older units is unknown and it is probably more recent than the oldest marker used. In addition, the displacements obtained from morphological markers may be underestimated due to infilling of tectonically depressed areas by younger deposits. The deformation accumulated since $350 \pm 40 \mathrm{ka}$ BP (or less) in the older units is large (fault scarps as high as $200 \mathrm{~m}$; Table 4). Considering a constant deformation rate it would be expected that the younger volcanic units (>31.4 $\pm 0.3 \mathrm{ka}$, Maund [1985]) would be faulted,

$\begin{array}{llll}\text { Structure } & \text { SRL (m) } & M_{w}(\text { from M/SRL }) & \text { RA }\left(\mathrm{km}^{2}\right) \quad M_{w}(\text { from M/RA) }\end{array}$

Table 5. Maximum expected magnitudes from surface rupture length (SRL) and rupture area (RA) for Graciosa faults. M/SRL $\mathrm{M}=5.08+1.16 \log (\mathrm{SRL}) ; \mathrm{M} / \mathrm{RA}-\mathrm{M}=4.07+0.98 \log (\mathrm{RA})$ from Wells and Coppersmith [1994]. 
with displacements of the order of $1 / 10$ of those observed in the older units. Thus, the fault scarps should have surface expression in their projection northwestwards into the NW Basaltic Platform and southeastwards into the Caldeira Volcano. This fact suggests slowing down of fault activity in Late Pleistocene and Holocene.

The present low seismicity, the large displacement accumulated by the older volcanic units, and the fact that no deformation is observed in the youngest areas of the island suggest that slip-rates must have been higher in the near past. This period with higher sliprates was followed by a phase dominated by important magmatism, during which Caldeira Volcano was built and the NW Basaltic Platform developed. This decrease of slip-rates must have increased the recurrence interval between fault rupturing-events. These observations in Graciosa are consistent with the occurrence of variations in the deformation rates in the archipelago, with periods with slip-rates higher or lower than the average motion predicted by global plate models, as proposed by Madeira [1998]. In that work the author estimated slip-rate values for a set of faults of the Central Group of Azores archipelago based on a detailed neotectonic analysis through tectonic mapping, chronostratigraphic correlations, and paleoseismological studies performed in São Jorge, Pico, and Faial Islands [Madeira 1998, Madeira and Brum da Silveira 2003]. However, while in São Jorge, Pico, and Faial, neotectonic data [Madeira 1998, Madeira and Brum da Silveira 2003] indicates recent slip-rates higher than those predicted by global plate kinematic models [DeMets et al. 1994, Sella et al. 2002, Fernandes et al. 2003, DeMets et al. 2010], in Graciosa what is observed is the opposite. The deformation integrated in a longer time frame is larger than what is observed for the last tens of thousands years.

Maximum expected magnitudes (MW) were estimated for the SHF, SSFF, ESFF, NSBF, and SSBF, using the surface rupture length (SRL)/Magnitude (MW) and the rupture area (RA)/Magnitude (Mw) correlations of Wells \& Coppersmith [1994], assuming the rupture of the full known length of the faults, a brittle crust thickness of $14 \mathrm{~km}$, based on the depth of the aftershocks from the January, 1st 1980 and July, 9th 1998 earthquakes (Hirn et al. 1980; Matias et al. 2007), and average fault dips of $70^{\circ}$. The estimated MW values range from 5.7 to 5.9 (Table 5). However, these are minimum values for the expected maximum magnitudes because the total length of the faults must be longer than the values used since the faults are concealed by recent volcanism and the small size of the island limits the observation of the full length of the faults that certainly extend to offshore areas. Nonetheless, the magnitudes estimated from neotectonic studies are within the range of magnitudes of instrumental seismicity in the archipelago (Table 1).

\section{Final remarks}

Several limitations prevent a more detailed neotectonic survey of Graciosa. Recent volcanic and epiclastic deposits mantling the topography conceal the surface expression of major tectonic structures. In most faults, exposed in lapilli quarries, basaltic lapilli deposits do not allow the generation of linear kinematic markers (slickensides). No faults were found presenting scarp heights and lithological conditions (e.g. absence of lava flows) favourable to be trenched for paleoseismological studies, thus contributing to seismic hazard assessment.

The paleostress analysis suggests that the region is affected by two different stress fields that can alternate in time, which are responsible for the generation of new faults or reactivation of pre-existing structures. The data suggest a diffuse Eu-Nu plate boundary expressed by a complex deformation zone, evidencing variable width in time, probably caused by changes in spreading rate between the Eu-NA and Nu-NA sections of the MAR, north and south of the triple junction. Thus the islands closer to the edge of the shear zone may become under the influence of different (inner and outer) stress fields.

The absence of seismic events producing surface rupture since settlement and the current low seismic activity in Graciosa Island, contrast with the youthful aspect of its tectonic morphology. The loss of geomorphic expression of the fault scarps in the areas covered by the younger units suggests the occurrence of a period of important tectonic activity before ca. $31 \mathrm{ka}$, with higher slip-rates than those observed in present times, responsible for the tectonic deformation of the central part of the island.

Despite the present low seismicity, historical records show that a few significant earthquakes affected Graciosa, since settlement in mid-15th century, causing fatalities and damage. Maximum magnitude values are probably underestimated due to unknown full length of the faults and as result of the island small size.

Currently, Graciosa seems to present low tectonic activity. Nevertheless, as the island is located in an important seismogenic zone, seismic hazard cannot be disregarded. The difficulty in developing paleoseismological studies constitutes a significant problem given that the neotectonic information available from traditional structural field analysis comprises a too long time window of the geological record than what is required 
for seismic hazard assessment. On the other hand, the historical and instrumental seismic data available for the Azores region only portray a very short period of the tectonic history of the analysed faults. Further neotectonic work, such as acquisition of bathymetric and seismic reflection surveys offshore Graciosa and re-evaluating the possibility of a paleoseismology analysis, will contribute to better understanding the tectonic processes and to characterize seismic hazard of emerged areas at the western segment of the $\mathrm{Eu}-\mathrm{Nu}$ plate boundary.

\section{Data and sharing resources}

Maps were made using ArcGIS 9.3 software, ESRI®. Topographic map of Graciosa Island is from IGeoE - Instituto Geográfico do Exército (2001). St. Cruz da Graciosa (Graciosa-Açores) - Folha 21. In: Carta Militar de Portugal - Série M889 2nd ed. Instituto Geográfico do Exército, Lisboa.

World topography and bathymetry from GEBCO_08 database (2010), IHO-UNESCO, General Bathymetry Chart of the Oceans, digital edition at http://www.gebco.net/data and products/gridded bathymetry data/.

Seismic map of Graciosa region was produced with data from CIVISA Database, Centro de Informação e Vigilância Sismovulcânica dos Açores, Centro de Vulcanologia e Avaliação de Riscos Geológicos da Universidade dos Açores.

Structural analysis was made using TectonicsFP $\AA$ software [Ortner et al. 2002].

Tectonic plate motion parameters calculated using the Science product support - Plate Motion Calculator from UNAVCO, http:/ / www.unavco.org/community science/science-support/crustal motion/dxdt/model.html.

Acknowledgments. Ana Hipólito is supported by a Ph.D. Grant from Fundação para a Ciência e Tecnologia (SFRH/BD/73664/2010). Fieldwork was supported by the Azores Regional Government / Serviço Regional de Protecção Civil e Bombeiros dos Açores through the project "Emergency Planning Studies", Contract Ref.FGF/2005. We appreciated and acknowledge the reviewers Francesco Mazzarini, João Fonseca, and an anonymous reviewer, the associate editor Salvatore Barba, and the volume editor Edoardo Del Pezzo for their careful reviews, suggestions, and helpful comments which contributed to significantly improve this manuscript.

\section{References}

Acosta, J., E. Uchupi, A. Munoz, P. Herranz, C. Palomo, M. Ballesteros and Z.E.E. Working Group (2003). Geologic evolution of the Canarian Islands of Lanzarote, Fuerteventura, Gran Canaria and La Gomera and comparison of landslides at these islands with those at Tenerife, La Palma and El Hi- erro, Mar. Geophys. Res., 24, 1-40.

Altamimi, Z., P. Sillard and C. Boucher (2002). ITRF2000: A new release of the International Terrestrial Reference Frame for earth science applications, J. of Geophys. Res., 107 (B10), 2214, 2-1 - 2-19. doi: 10.1029/2001JB000561.

Anderson, E. M. (1951). The dynamics of faulting, Oliver and Boyd (eds), Edinburgh, 2, 206 p.

Angelier, J. (1994). Paleostress determinations, In: Hancock, P.L. (Ed.), Continental Deformations. Pergamon Press, Tarrytown, NY, 53-100.

Borges, J.F., M. Bezzeghoud, E. Buforn, C. Pro and A. Fitas (2007). The 1980, 1997 and 1998 Azores earthquakes and its seismotectonic implications, Tectonophysics, 435, 37-54, doi:10.1016/j.tecto.2007.01.008.

Borges, J.F., B. Caldeira, M. Bezzeghoud and E. Buforn (2008). Sismicidade e sismotectónica dos Açores: implicações geodinâmicas, In Sousa Oliveira, C., A. Costa, J.C. Nunes (eds.), Sismo 1998 - Açores. Uma década depois. 99-110, ISBN: 978-989-20-1223-0.

Borges, J.F. and E. Burfon (2008). Recent seismic activity in the Azores region, In Sousa Oliveira, C., A. Costa, J.C. Nunes (eds.), Proceedings of the International Seminar on Seismic Risk and Rehabilitation on the 10th Anniversary of the July 91998 Azores Earthquake, ISBN 978-989-20-1235-3.

Buforn, E., A. Udías and M. Colombas (1988). Seismicity, source mechanisms and tectonics of the AzoresGibraltar plate boundary, Tectonophysics, 152, 89-118.

Calais, E., C. DeMets and J.-M. Nocquet (2003). Evidence for a post-3.16-Ma change in Nubia-Eurasia-North America plate motions?, Earth Planet. Sci. Lett. 216, 81-92, doi:10.1016/S0012-821X(03)00482-5.

Cannat, M., A. Briais, C. Deplus, J. Escartín, J. L. Georgen, S. Mercouriev, C. Meyzen, M. Muller, G. Pouliquen, A. Rabain and P. Silva (1999). Mid-Atlantic Ridge - Azores hotspot interactions: along-axis migration of a hotspot-derived event of enhanced magmatism 10 to 4Ma ago, Earth Planet. Sci. Lett., 173, 257-269.

Canto, E. and F. Afonso Chaves (1890). Arquivo dos Açores Online, Digital issue of Arquivo dos Açores (1980 1984), Azores University, XI, 572 p., http:/ / www.uac.pt/ arquivoacores/.

Carmo, R. (2004). Geologia estrutural da região Povoação - Nordeste (ilha de São Miguel, Açores), M.Sc. Thesis, Azores University, 133 p.

DeMets, C., R. Gordon, D. Argus and S. Stein, (1994). Effect of recent revisions to the geomagnetic reversal time scale on estimates of current plate motions, Geophys. Res. Lett., 21(20), 2191-2194.

DeMets, C., R.G. Gordon and D.F. Argus (2010). Geo- 
logically current plate motions, Geophy. J. Int., 181, 1-80.

Dias, N.A., L. Matias, N. Lourenço, J. Madeira, F. Carrilho and J.L. Gaspar (2007). Crustal seismic velocity structure near Faial and Pico Islands (Azores), from local earthquake tomography, Tectonophysics, 445, 301-317, doi: 10.1016/j.tecto.2007.09.001.

Escartín, J.; M. Cannat, G. Pouliquen and A. Rabain (2001). Crustal thickness of V-shaped ridges south of the Azores: Interaction of the Mid-Atlantic Ridge $\left(36^{\circ}-39^{\circ} \mathrm{N}\right)$ and the Azores hot spot, J. Geophys. Res., 106 (B10) 21,719-21,735.

Féraud, G., I. Kaneoka and C.J. Allégre (1980). K-Ar Ages and Stress Pattern in the Azores - Geodynamic Implications, Earth Planet. Sci Lett., 46(2), 275-286.

Fernandes, R. M. S., B. A. C. Ambrosius, R. Noomen, L. Bastos, M.J.R. Wortel, W. Spakman and R. Govers (2003). The relative motion between Africa and Eurasia as derived from ITRF2000 and GPS data, Geophys. Res. Lett., 30 (16), 1828, 1-1 - 1-5, doi: 10.1029/2003GL017089.

Fernandes, R.M.S., L. Bastos, J. M. Miranda, N. Lourenço, B. A. C. Ambrosius, R. Noomen and W. Simons (2006). Defining the Plate Boundaries in the Azores Region, J. Volcanol. Geoth. Res., 156, 1-9, doi: 10.1016/j.jvolgeores.2006.03.019.

Ferreira, T., J. L. Gaspar and G. Queiroz (1993). Considerações sobre as emanações gasosas da Furna do Enxofre (Ilha Graciosa, Açores), Açoreana VII (4), 603-612.

Gamacho, G. A., F. G. Montesinos, R. Vieira and J. Arnoso (2001). Modelling of crustal anomalies of Lanzarote (Canary Islands) in light of gravity data, Geophys. J. Int., 147, 403-414.

Gaspar, J.L. and G. Queiroz (1995). Carta Vulcanológica dos Açores, ilha Graciosa. Universidade dos Açores e Câmara Municipal de Santa Cruz da Graciosa (Eds).

Gaspar, J.L. (1996). Ilha Graciosa (Açores): História Vulcanológica e Avaliação do Hazard, Ph.D. Thesis, Azores University, 361p.

Gaspar, J. L., C. Goulart, G. Queiroz, D. Silveira and A. Gomes (2004). Dynamic structure and data sets of a GIS database for geological risk analysis in the Azores volcanic islands, Nat. Hazard Earth Sys. Sciences, 4, 233-242.

Gente, P., J. Dyment, M. Maia and J. Goslin (2003). Interaction between the Mid-Atlantic Ridge and the Azores hot spot during the last 85 Myr: Emplacement and rifting of the hot spot-derived plateaus, Geochem. Geophys. Geosy., 4 (10), 8514, 23 p., doi: 10.1029/2003GC000527.

Grimisson, N. L. and W.-P. Chen (1986). The AzoresGibraltar plate boundary: focal mechanisms, depths of earthquakes and their tectonic implications, J. of Geophys. Res., 92, (B2), 2029-2047.

Hipólito, A. (2009). Geologia Estrutural da ilha Graciosa. Enquadramento no âmbito da junção tripla dos Açores, M.Sc. Thesis, Azores University, 155 p.

Hirn, A., H. Haessler, P. Hoang-Trong, P. Wittlinger and L. Mendes-Victor (1980). Aftershock sequence of the January $1^{\text {st }}, 1980$ earthquake and present-day tectonics in the Azores, Geophys. Res. Lett., 7 (7), 501-504.

IGeoE - Instituto Geográfico do Exército (2001). St. Cruz da Graciosa (Graciosa-Açores) - Sheet 21, Carta Militar de Portugal - Série M889 2nd ed., Instituto Geográfico do Exército, Lisboa.

INMG and LNEC (1986). Sismicidade histórica e instrumental do arquipélago dos Açores (Sismos sentidos no período 1444-1980), Estudos realizados para o Novo Hospital de Ponta Delgada, INMG/LNEC open-file report, Lisbon, 1.

Kreemer, C., W. E. Holt and A. J. Haines (2003). An integrated global model of present-day plate motions and plate boundary deformation, Geophys. J. Int., 154, 8-34.

Lourenço, N., J. Luís and J. M. Miranda (1997). Azores triple junction bathymetry, Map edited by Science Faculty, Lisbon University and Algarve University, 1 Sheet.

Lourenço, N., J. M. Miranda, J. Luís, A. Ribeiro, L. Mendes-Victor, J. Madeira and H. Needham (1998). Morphotectonic analysis of the Azores Volcanic Plateau from a new bathymetric compilation of the area, Mar. Geophys. Res., 20, 141-156.

Luís, J. F., J. M. Miranda, A. Galdeano and P. Patriat (1998). Constraints on the structure of the Azores spreading center from gravity data. Mar. Geophys. Res., 20, 157-170.

Luís, J.F. and J. M. Miranda (2008). Reevaluation of magnetic chrons in the North Atlantic between $35^{\circ} \mathrm{N}$ and $47^{\circ} \mathrm{N}$ : Implications for the formation of the Azores Triple Junction and associated plateau, J. Geophys. Res., 113, B10105, doi:10.1029/2007Jb005573.

Machado, F. (1959). Submarine pits of the Azores Plateau, Bulletin Volcanol. (sér. II), 21, 109-116.

Madeira, J. (1986). Geologia estrutural e enquadramento geotectónico da ilha de Santa Maria (Açores), M.Sc. Thesis, Lisbon University, 107 p.

Madeira, J. (1998). Estudos de neotectónica nas ilhas do Faial, Pico e São Jorge: uma contribuição para o conhecimento geodinâmico da junção tripla dos Açores, Ph.D. Thesis, Lisbon University, 428 p.

Madeira, J. and A. Ribeiro (1990). Geodynamic models for the Azores triple junction: a contribution from tectonics, Tectonophysics, 184, 405-415.

Madeira, J. and A. Brum da Silveira (2003). Active Tec- 
tonics and first paleoseismological results in Faial, Pico and São Jorge Islands (Azores, Portugal), Annals of Geophysics, 46 (5), 733-761.

Madureira, P., M. Moreira, J. Mata and J. C. Allegre (2005). Primitive helium and neon isotopes in Terceira island (Azores archipelago), Earth Planet. Sci. Lett, 233, 429-440, doi: 10.1016/j.epsl.2005.02.030.

Matias, L., N. A. Dias, I. Morais, D. Vales, F. Carrilho, J. Madeira, J. L. Gaspar, L. Senos and A. Brum da silveira (2007). The 9th of July 1998 Faial Island (Azores, North Atlantic) seismic sequence, J. Seismol., 11, 275-298, doi: 10.1007/s10950-007-9052-4.

Matos, A. T. (1982). Uma memória setecentista inédita da ilha Graciosa, Boletim do Instituto Histórico da Ilha Terceira, XL, 375-396.

Maund, J. (1985). The Volcanic Geology, Petrology and Geochemistry of Caldeira Volcano, Graciosa, Azores, and its bearing on contemporaneous felsicmafic oceanic island volcanism, Ph.D. Thesis, University of Reading, $333 \mathrm{pp}$.

Mckenzie, D. (1972). Active tectonics of the Mediterranean region, Geophys. J. R. Astron. Soc., 30, 109185.

Mendes, V. B., J. Madeira, A. Brum da Silveira, A.Trota, P. Elósegui and J. Pagarete (2013). Contemporary deformation of S. Jorge Island, Azores, from episodic GPS measurements (2001-2011). Adv. Space Res., 51, 1581-1592, doi: 10.1016/j.asr.2012.10.019.

Mezcua, J., J. Rueda and J. M. Martínez Solares (1991). Seismicity of the Ibero-Maghrebian region, In: J. Mezcua and A. Udías (Eds.), Seismicity, seismotectonics and seismic risk of the Ibero-Maghrebian region, Instituto Geografico Nacional, Madrid, 8: 17-28.

Miranda, J., L. Mendes-Victor, J. Simões, J. Luís, L. Matias, H. Shimamura, H. Shiobara, H. Nemoto, H. Mochizukli, A. Hirn and J. Lépine (1998). Tectonic setting of the Azores Plateau deduced from a OBS survey, Mar. Geophys. Res., 20, 171-182.

Miranda J.M., A. Navarro, J. Catalão and R.M.S. Fernandes (2012). Surface displacement field at Terceira island deduced from repeated GPS measurements. J. Volcanol. Geoth. Res., 217-218, 1-7, doi:10.1016/j.jvolgeores.2011.10.009.

Moniz, A. (1883). Ilha Graciosa (Açores) - Descripção Historica e Topographica, Angra do Heroísmo, 299 p.

Moreira, V.S. (1991). Historical seismicity and seismotectonics of the area situated between the Iberian Peninsula, Morocco, Selvagens and Azores islands, In J. Mezcua and A. Udías (Eds.), Seismicity, seismotectonics and seismic risk of the Ibero-Maghrebian region, Instituto Geografico Nacional, Madrid, 8: 213-225.
Needham, H. and J. Francheteau (1974). Some characteristics of the rift valley in the Atlantic Ocean near $36^{\circ} 48^{\prime}$ north, Earth Planet. Sci. Lett., 22, 29-43.

Ortner, H., F. Reiter and P. Acs (2002). Easy handling of tectonic data: the programs TectonicsVB for Mac and TectonicsFP for Windows, Comput. Geosci., 28, 1193-1200.

Pereira, V. C. D. (1986). Igrejas e ermidas da Graciosa, Edição comemorativa do $500^{\circ}$ aniversário da elevação a vila de Santa Cruz da Graciosa. Direção Regional dos Assuntos Culturais/Secretaria Regional Da Educação e Cultura, Angra do Heroísmo, 458 p.

Petit, J.-P. (1987). Criteria for the sense of movement on fault surfaces in brittle rocks, J. Struct. Geol., 9, 597608.

Reches, Z. (1983). Faulting of rocks in three-dimensional strain fields. II: Theoretical analysis, Tectonophysics, 95, 133-156.

Reches, Z. and J. H. Dieterich (1983). Faulting of rocks in three-dimensional strain fields. I: Failure of rocks in poliaxial, servo control experiments, Tectonophysics, 95, 111-132.

Schilling, J-G., 1975. Azores mantle blob: rare-earth evidence, Earth Planet. Sci. Lett., 25, 103-115.

Sella, G., T. H. Dixon and A. Mao (2002). REVEL: a model for recent plate velocities from space geodesy, J. Geophys. Res., 107 (B4), 2081, 11-1 - 11-12, doi: 10.1029/2000JB000033.

Silva, M. (2005). Caracterização da sismicidade histórica dos Açores com base na reinterpretação de dados de macrossísmica: contribuição para a avaliação do risco sísmico nas ilhas do Grupo Central, Ph.D. Thesis, Azores University, 163 p.

Silva, R., J. Havskov, C. Bean and N. Wallenstein (2012). Seismic swarms, fault plane solutions, and stress tensors for São Miguel Island central region (Azores), J. Seismol., 16(3), 389-407.

Silveira, G., E. Stutzmann, A. Davaille, J.-P. Montagner, L. Mendes-Victor and A. Sebai (2006). Azores hotspot signature in the upper mantle, J. Volcanol. Geoth. Res., 156, 23-34, doi:10.1016/j.jvolgeores.2006.03. 022.

Trota A. (2008). Crustal deformation studies in $S$. Miguel and Terceira Islands (Azores). Volcanic unrest evaluation in Fogo/Congro area (S. Miguel). Ph.D. Thesis, University of Azores, 281 pp.

Udías, A., A. Lopez Arroyo and J. Mezcua (1976). Seismotectonics of the Azores-Alboran region, Tectonophysics, 31, 259-289.

Udías, A., A. F. Espinoza, J. Mezcua, E. Buforn, R. Vegas, S. P. Nishenko, J. M. Martínez-Solares and A. Lopez Arroyo (1986). Seismicity and tectonics of the North African-Eurasian plate boundary (Azores-IberiaTunisia), U. S. Geol. Survey Open-File Report, 86-626. 
Udías, A. (1980). Seismic stresses in the region AzoresSpain-Western Mediterranean, Rock Mech., suppl. 9, 75-84.

Vogt, P.R. and W. Y. Jung (2004). The Terceira Rift as hyper-slow, hotspot dominated oblique spreading axis: A comparison with other slow-spreading plate boundaries, Earth Planet. Sci. Lett, 218, 77-90. doi:10.10116/S0012-821X(03)00627-7.

Wells, D. L. and K. J. Coppersmith (1994). New empirical relationships among Magnitude, Rupture Length, Rupture Width, Rupture Area, and Surface Displacement, Bull. Seism. Soc. Am., 84 (4), 974-1002.

Yang, T., Y. Shen, S. Lee, S. C. Solomon and S.-H. Hung (2006). Upper mantle structure beneath the Azores hotspot from finite-frequency seismic tomography, Earth Planet. Sci. Lett., 250, 11-26, doi: 10.1016/j.epsl.2006.07.031.

${ }^{\star}$ Corresponding author: Ana Hipólito,

Centro de Vulcanologia e Avaliação de Riscos Geológicos da Universidade dos Açores, CVARG, Açores, Portugal;

email: ana.rc.hipolito@azores.gov.pt 